2013

\title{
Confronting Science: Expert Evidence and the Confrontation Clause
}

David H. Kaye

Penn State Law

Jennifer L. Mnookin

UCLA Law

Follow this and additional works at: http://elibrary.law.psu.edu/fac_works

Part of the Evidence Commons, and the Science and Technology Law Commons

\section{Recommended Citation}

David H. Kaye and Jennifer L. Mnookin, Confronting Science: Expert Evidence and the Confrontation Clause, 2012 Sup. Ct. Rev. 99 (2013).

This Article is brought to you for free and open access by the Faculty Works at Penn State Law eLibrary. It has been accepted for inclusion in Journal Articles by an authorized administrator of Penn State Law eLibrary. For more information, please contact ram6023@psu.edu. 
DRAFT 2/23/13

for THE SUPREME COURT REVIEW, VOL. 2012

(C) 2013 BY THE UNIVERSITY OF CHICAGO. ALL RIGHTS RESERVED.

978-0-226-05201-4/2013/2012-0003\$10.00

JENNIFER MNOOKIN and DAVID KAYE

\section{CONFRONTING SCIENCE: EXPERT EVIDENCE AND THE CONFRONTATION CLAUSE*}

For most of its history, the Supreme Court had little to say about expert and scientific evidence. Then tranquility turned to turmoil. In the closing decade of the twentieth century, a trilogy of cases, starting with Daubert $v$ Merrell Dow Pharmaceuticals, ${ }^{1}$ introduced and elaborated on a new standard for admitting scientific evidence under the Federal Rules of Evidence. This trilogy, on which much ink has been spilled over the past two decades, spelled out the need for judges to engage in preliminary gatekeeping to determine the admissibility of expert evidence. While the evaluative criteria by which courts were to assess scientific validity were purposefully flexible, and trial judges were to be given substantial discretion in these judgments, these cases both reflected and generated a sense that scientific evidence required special attention and careful scrutiny. ${ }^{2}$

Now, in the opening decades of a new millennium, another expert-evidence trilogy has appeared. This new trilogy arises not from a statute but from the Constitution: it relates to the intersection between the Confrontation Clause of the Sixth Amendment and the many varieties

* Jennifer L. Mnookin is Vice Dean and Professor of Law, UCLA School of Law. David H. Kaye is Distinguished Professor and Weiss Family Scholar, School of Law, and Graduate Faculty Member, Forensic Science Program, The Pennsylvania State University.

AUTHORS' NOTE: This article benefitted from comments posted on the Evidence Professors Discussion List, from exchanges with Edward Imwinkelried and Jeffrey Fisher, and from an update to George Fisher's teacher's manual for Evidence (Foundation 2d ed 2012). Portions of Section II.A.2 and II.B draw on material from David H. Kaye, David E. Bernstein and Jennifer L. Mnookin, The New Wigmore-A Treatise on Evidence: Expert Evidence (Aspen Supp. 2012).

1509 US 579 (1993).

${ }^{2}$ The trilogy consists of Daubert, 509 US at 579, General Electric Co v Joiner, 522 US 136 (1997), and Kumho Tire Co v Carmichael, 526 US 137 (1999). 
of forensic science evidence that often provide a mainstay of prosecutors' cases against criminal defendants. The origins of this new trilogy date to 2004, when, in Crawford $v$ Washington $^{3}$ the Supreme Court substantially changed its understanding of how the Confrontation Clause applies to hearsay evidence. Crawford was a seemingly mundane murder case that did not involve or address expert or scientific evidence. There were no fingerprints to compare, no drugs to identify, no DNA to analyze, and no fMRI tests to run. The sole disputed question was selfdefense. But it was inevitable that Crawford's doctrinal framework, with its focus on the newlyemphasized category of the "testimonial," would be applied to expert evidence and that thorny doctrinal difficulties would emerge.

The basic questions seem, at first glance, straightforward enough. To satisfy the Confrontation Clause, must those forensic scientists or technicians who produce inculpatory evidence against a criminal defendant testify live, or will sworn affidavits and reports suffice? If live testimony is required, what, if anything, can the testifying witnesses say about procedures they did not conduct personally? If multiple analysts contribute to producing a forensic test result, which ones must appear in court? But these questions turn out not to be so easily answered. The Court has issued three expert-evidence-related Confrontation Clause decisions in the past four years, and each one has generated at least as many questions as answers. Moreover, each of these cases is marked by narrow majorities, fractious and fractured opinions, and unsatisfying doctrinal elisions. In the most recently decided case, Williams $v$ Illinois, ${ }^{4}$ the court issued a bewildering array of opinions in which majority support for admitting the evidence at issue was awkwardly knitted together out of several incompatible doctrinal bases. The result, at least for now, is continued anxiety and confusion over the Confrontation Clause as it applies to forensic science evidence.

The Court's efforts to bring clarity to this area, especially in Williams, have been muddled by its struggle to determine precisely how to think about hearsay evidence in the context of expert evidence and the Confrontation Clause. As every student of evidence knowsthough often imperfectly understands-evidence is considered to be hearsay only if it is introduced for the truth of the matter asserted. The phrase is more easily remembered than understood. What it means to introduce an item of evidence "for the truth of the matter asserted" has confused generations of law students, lawyers, and jurists. ${ }^{5}$ In Williams, four Justices thought it clear that a laboratory report, which was fundamental to the testifying expert's conclusions, was mentioned by the expert for a purpose other than its truth. Five Justices thought it equally obvious that it was discussed solely for its truth-but because one of them agreed on other grounds with the other four Justices' conclusion regarding the scope of the Confrontation Clause, a majority of the Court deemed the testimony referencing the laboratory report to be admissible despite the absence of the opportunity to confront the report's author.

When it comes to understanding what "the truth of the matter asserted" means, we believe that neither group of Justices has it quite right. Understanding what it means for

\footnotetext{
${ }^{3} 541$ US 36 (2004).

${ }^{4} 132$ S Ct 2221 (2012).

${ }^{5}$ See, for example, Peter Murphy and David N. Barnard, Evidence and Advocacy 19 (Blackstone 1984) (To some "judges, practitioners and students (not to mention occasional law teachers) . . . the rule against hearsay has always been an awesome and terrifying mystery. Like its partner in terror, the rule against perpetuities, the rule against hearsay ranks as one of the law's most celebrated nightmares. To many practitioners, it is a dimly remembered vision, which conjures up confused images of complex exceptions and incomprehensible and antiquated cases.”).
} 
something to be offered for the "truth of the matter asserted" can be complicated enough in the general hearsay context. But in the expert evidence setting, it is even more difficult, because courts have long been willing, sometimes to the point of absurdity, to say that information testifying experts detail to the jury in the guise of describing the basis for their conclusions is not introduced for its truth. On the particular facts of Williams, we maintain that notwithstanding several Justices' argument to the contrary, there were no plausible grounds for deeming the evidence introduced for a purpose other than its truth. But we do recognize that in other, relatively limited instances, expert basis evidence might legitimately be introduced for a purpose other than its truth. Since this "not for the truth" rationale is the dominant argument offered by the Williams Court for justifying admissibility of the expert's articulation of the basis, ascertaining this argument's legitimate reach is important.

Yet precision on this doctrinal point is insufficient to provide adequate guidance and clarity. The ongoing anxiety about how to think about expert evidence and the Confrontation Clause exists in large part because is the Court has yet to face directly a set of larger, background concerns. This second expert-evidence trilogy reveals significant uncertainty about how, and to what extent, scientific evidence should be treated as special or distinct from other kinds of evidence. While the Daubert trilogy explicitly requires special scrutiny of expert evidence, other rules of evidence are structured to provide special privileges and deference to experts, generally letting them, for example, rely on hearsay and other inadmissible evidence in reaching their conclusions. ${ }^{6}$ How do these privileges generated by other evidence rules-and, more generally, the sense that scientific evidence sometimes deserves special treatment-fit with the Confrontation Clause and its limits on testimonial hearsay? Is there any space for heightened deference to experts within the Confrontation Clause framework? For Confrontation Clause purposes, should scientific evidence be seen as just the same, structurally, as any other kind of evidence, or are there aspects related to its mode of creation and transmission that might warrant distinctive procedures? While we will not endeavor to answer this set of questions fully in this essay, we argue that the Court will not be able effectively or coherently to resolve the doctrinal issues surrounding forensic science evidence and the Confrontation Clause without tackling these questions head-on.

More specifically, we will suggest that scientific and expert evidence might warrant some limited special treatment, based on what we see as one of the most critical dimensions of scientific knowledge production - that it is a is a collective, rather than an individual enterprise. Scientific tests, research and study, from high energy physics to medical research to forensic science procedures, are not carried out solo. This feature of science has two important consequences: first, it means that the scientific process typically depends on a certain degree of epistemic deference by scientists to their collaborators. Scientists and experts inevitably rely and build on facts, data, opinions, test results, of others; they do not merely defer to the authority of others, but they are, fundamentally, epistemically dependent on one another. It also means that scientists are engaged in what we might call "distributed cognition" - the knowledge that is produced is not entirely held by any one person, but stretches across a network. This reticulate

\footnotetext{
${ }^{6}$ FRE 702 permits experts to give opinions. FRE 703 permits them to rely on inadmissible evidence "[i]f experts in the particular field would reasonably rely on those kinds of facts or data in forming an opinion on the subject . . .." An amendment to this rule sought to partially close this backdoor use of hearsay. It added the proviso that "if the facts or data would otherwise be inadmissible, the proponent of the opinion may disclose them to the jury only if their probative value in helping the jury evaluate the opinion substantially outweighs their prejudicial effect.”
} 
reality creates significant tensions with the current Confrontation Clause framework. We suggest that recognizing these characteristics of science should invite courts to engage in a modest form of scientific exceptionalism within Confrontation Clause jurisprudence, through efforts to create procedures that do respect the fundamental values of the Confrontation Clause, but also adapt when necessary, to the epistemic structures and processes of science.

We first describe this new trilogy, focusing especially on the emerging tensions in these cases about whether scientific evidence warrants or deserves special treatment. We then look carefully at the "truth of the matter asserted" argument in the plurality opinion written by Justice Alito in Williams. We argue that the plurality's approach is ingenious but indefensible on the facts as given. In the final section, we offer thoughts on whether there ought to be a form of "science exceptionalism" within the Confrontation Clause-that is, to what extent, and why, a special or distinctive understanding the clause in the context of expert evidence might be warranted.

\section{ThE LABoratory Trilogy: Melendez-Diaz, Bullcoming, AND WilliamS}

In Crawford, the Supreme Court recast its approach to defendant's Sixth Amendment right to be "confronted with the witnesses against him."7 For the previous several decades, the touchstone for assessing whether hearsay evidence implicated the Confrontation Clause was the hearsay evidence's reliability. If the evidence had adequate indicia of reliability-and all "firmly-rooted" hearsay exceptions were conclusively deemed to have such indicia - then its introduction did not violate the Clause. If an item of hearsay evidence did not fall into a "firmly rooted" hearsay safe harbor, then it had to be excluded under the Confrontation Clause unless it had particularized "indicia of reliability." " Crawford rejected this reliability-plus-tradition framework both on functional and on historical-originalist grounds. Functionally, the Court deemed reliability too murky to be useful—too subjective, amorphous, and unpredictable to provide significant operational guidance to courts or to lead to consistent admissibility outcomes. ${ }^{9}$ But still worse, in the Court's view, the reliability approach did not comport with original understandings of the boundaries of the Confrontation Clause. ${ }^{10}$ Justice Scalia's majority opinion declared that the right question to be asked of hearsay statements by a nontestifying declarant that potentially implicated the Confrontation Clause was whether they were or were not testimonial. Were these statements, in other words, akin to, or a substitute for, in-court testimony? If so, they generally had to be excluded, for the Constitution, the Court held, barred the prosecution from introducing "testimonial statements of a witness who [does] not appear at trial unless he [is] unavailable to testify, and the defendant had . . . a prior opportunity for crossexamination."11

This concept of the testimonial is, of course, not self-explicating. At its narrowest, testimonial evidence might be limited to those formalized materials most similar to in-court testimony (like affidavits, depositions, sworn confessions). At its broadest, it might include any statements made in circumstances in which the speaker or listener would reasonably understand

\footnotetext{
${ }^{7}$ US Const Amend VI.

${ }^{8}$ Ohio v Roberts, 448 US 56, 72 (1980).

${ }^{9}$ Crawford, 541 US at 63 ("Reliability is an amorphous, if not entirely subjective, concept.").

${ }^{10}$ Id at $43-50$.

${ }^{11}$ Id at 53-54.
} 
its possible relevance to a future criminal proceeding. The Court canvassed several formulations, ranging from the narrow to the broad, but since the statements at issues in the case were, in the Court's view, testimonial under any plausible definition of the term, it elected to "leave for another day" any "comprehensive definition" of the pivotal term that now marks the perimeter of the Confrontation Clause. ${ }^{12}$ Six justices joined Justice's Scalia's majority opinion, while Chief Justice Rehnquist wrote a concurrence (joined by Justice O'Connor) suggesting that there was actually no need, on either originalist or functionalist grounds, to overturn Ohio v Roberts, and that the Court's choice not to spell out more carefully the contours of its critical category of "testimonial evidence" was sure to generate myriad difficulties for courts and prosecutors.

As we noted at the outset, Crawford itself did not involve expert evidence. The statement at issue in the case was a recorded statement the defendant's wife had made to the police- she was unavailable to testify at trial because of the state's rules of marital privilege. But lower courts soon began wrestling with a lively set of issues relating to expert evidence and the Confrontation Clause, especially with regard to often-used forensic science evidence-matters like chemical drug testing, blood and urine analysis for alcohol or other substances, autopsy reports, and DNA profiling. In most states, some of these forms of forensic science evidence were often introduced via sworn certificate rather than live testimony. Did Crawford jeopardize this routine practice? What if many years passed between a forensic test and a trial, and the original analyst was unavailable? Could someone else then testify about those test results? More generally, could analysts regularly testify about one another's test results, as was frequently the practice prior to Crawford? Did it matter whether the testifying analyst was a supervisor or regularly conducted the kind of test at issue? And what if multiple analysts had all played some role in the tests that led to a specific conclusion — did each and every one of them really have to testify? If not, then whose testimony was required?

Lower courts began to work through the potential implications of Crawford in this variety of circumstances. For the most part, they were reluctant to read Crawford as requiring any significant changes to the preexisting methods for introducing forensic science testimony. In the first years following the Crawford decision, most (though certainly not all) trial courts instead endeavored to shoehorn the traditional methods for presenting forensic science testimony into this new framework without requiring modifications. ${ }^{13}$ They argued, for example, that forensic science reports were exempt from the Confrontation Clause because they were business records, because they were factual, because they were neutral, or because it was just too impractical to require the state to produce the authors of these reports or the individuals who conducted the testing. ${ }^{14}$

In Melendez-Diaz v Massachusetts, ${ }^{15}$ the first case in the laboratory trilogy, the Supreme Court weighed in on how the Crawford framework applied to expert testimony. In this case, the prosecution presented a state laboratory analyst's sworn certificates asserting that plastic bags found near the defendant contained cocaine of a certain weight. A state statute exempted such certificates from the rule against hearsay; indeed, the vast majority of states had similar statutes

\footnotetext{
${ }^{12}$ Id at 53-54.

${ }^{13}$ For a discussion of the lower courts' responses to forensic science evidence in the wake of Crawford, see Jennifer L. Mnookin, Expert Evidence and the Confrontation Clause After Crawford v. Washington, 15 Brooklyn J L \& Pol 790, 847-50 (2007).

${ }^{14}$ See generally id.

${ }^{15} 557$ US 305 (2009).
} 
on their books. ${ }^{16}$ The defendant objected that although Massachusetts was free to limit or abolish the hearsay rule, introducing these certificates without the testimony of the analyst violated the Confrontation Clause. The basic question, therefore, was whether these certificates of analysis were testimonial. Again writing for the majority, Justice Scalia did not find this question difficult in the least: "There is little doubt that the documents at issue in this case fall within the 'core class of testimonial statements.", 17 They were, at essence, affidavits made precisely in order to substitute for testimony. Rejecting arguments that forensic scientists should be treated differently than other witnesses, Melendez-Diaz held that a signed, sworn piece of paper was no substitute for the actual testimony of the government chemists who conducted the tests.

From one perspective, this holding was unsurprising. It would be difficult to devise a coherent definition of "testimonial" that did not include sworn certificates like these. Indeed, Justice Scalia suggested that this holding is a simple extension of Crawford, signaling to reluctant lower courts that the Court meant for them to take its newly created category seriously even if it did require significant modification to the methods for adducing forensic evidence.

Justice Scalia's majority was fragile, however. Four justices dissented, arguing that Crawford and its immediate progeny dealt with "ordinary witnesses," not scientific and expert evidence, and "the Court should have done the sensible thing and limited its holding to witnesses as so defined." 18 The dissenters, led by Justice Kennedy, and joined by Chief Justice Rehnquist, and Justices Breyer and Alito, emphasized that numerous analysts may all play a role in conducting a routine chemical test for drugs, and that it would be absurd to require every one of them to show up to testify in every case. ${ }^{19}$

The dissent also attempted to spell out several ways in which forensic analysts differ from "conventional” or "ordinary" witnesses. The opinion points out that at trial ordinary witnesses relate events they observed in the past, and often these events are singular or at least atypical, whereas forensic analysts have made, in accordance with their standard protocols, nearcontemporaneous written observations of their routinely and regularly-conducted tests. In addition, their in-court testimony more likely derives from these written observations than from any authentic memory of the specific test in question. Forensic analysts, the dissent suggested, are also more removed from the crime than many ordinary fact witnesses and are thereby unlikely to be as affected by the look-him-in-the-eye aspect of testifying in person. ${ }^{20}$ Moreover, in making the statements that are presumed by the majority to be testimonial, experts are following scientific protocols rather than responding to interrogation, and they lack an overtly adversarial or accusatory relationship to the defendant. ${ }^{21}$

Justice Scalia's majority opinion flatly rejected these arguments, emphasizing that it is not obvious that "what respondent calls 'neutral scientific testing' is either as neutral or as reliable as respondent suggests," and that "Confrontation is designed to weed out not only the fraudulent analyst, but the incompetent one as well." 22 In this first case of the trilogy, then, we see the outlines of a critical divide over whether scientific evidence warrants special treatment

\footnotetext{
${ }^{16}$ For a detailed discussion of the varieties of statutes permitting forensic ipse dixit testimony via certificate, see generally Pamela R. Metzger, Cheating the Constitution, 59 Vand L Rev 475 (2006).

${ }^{17}$ Melendez-Diaz, 557 US at 310.

${ }^{18}$ Id at 331 (Kennedy dissenting).

${ }^{19}$ Id at 332-35.

${ }^{20}$ Id at 339-40.

${ }^{21}$ Id at 345-46.

${ }^{22}$ Id at 318-19 (Scalia).
} 
under the Confrontation Clause. The thrust of the dissent's argument is less that these certificates are not testimonial, and more that these kinds of expert evidence should be excluded from the Confrontation Clause's strictures both for practical reasons and because of the distinctive qualities of science. Given the other available methods of evidentiary regulation, coupled with the protections provided by scientific procedures themselves, "the Confrontation Clause is simply not needed for these matters." ${ }^{23}$ To boil the dispute down to its basics, the dissent believes that the Confrontation Clause's provisos ought to apply differently to scientific evidence; by contrast, the majority wants to treat scientific evidence in precisely the same manner as any other kind of testimony.

While, doctrinally, Melendez-Diaz clarified that forensic science reports (at least if sufficiently formal) ${ }^{24}$ were testimonial, it left many questions unresolved. Two years later, in Bullcoming $v$ New Mexico, ${ }^{25}$ the evidence at issue was a state laboratory report on the defendant's blood-alcohol concentration (BAC). This time, the prosecution had offered the live testimony of an analyst about the report. However, because the laboratory analyst who had actually conducted the test was on unpaid leave, the prosecution substituted another employee of the same laboratory. The testifying witness had no involvement in the specific test or in the preparation of the report, but he was familiar with the procedures used and had run this same test himself in other cases. This was enough to satisfy the New Mexico Supreme Court. Begrudgingly granting that the blood alcohol report was testimonial, ${ }^{26}$ it deemed the absent analyst's role to be that of a "mere scrivener who simply transcribed the results generated by a gas chromatograph machine." 27 Moreover, the Court concluded that the testimony of a qualified alternative expert from the laboratory, who could, under the rules of evidence, rely upon this report to form his own opinion, who was knowledgeable about the testing procedure at issue, and who was available for cross-examination, provided the defendant with a constitutionally adequate opportunity for confrontation.

New Mexico’s Rules of Evidence, like Federal Rule of Evidence 703 (and like nearly all state evidence rules), permit experts to rely on materials that have not been (and perhaps could not be) admitted into evidence, when forming their own expert opinions, so long as the materials are of a type experts in the field would reasonably rely upon in forming their opinions. ${ }^{28}$ This is, of course, one of the rules of evidence that treats experts as "special," giving them distinctive testimonial privileges that lay witnesses lack. Not only are experts expected to give opinions, whereas opinion testimony from lay witnesses is disfavored, ${ }^{29}$ but these opinions can be based on a wide array of materials, even including inadmissible evidence. The underlying theory is that within their sphere of expertise, experts should be given significant leeway to determine what to rely upon and how much warrant it should have (just as they do when using their expertise

\footnotetext{
${ }^{23}$ Id at 340 (Kennedy dissenting).

${ }^{24}$ Justice Thomas filed a one-paragraph concurrence stating that the Confrontation Clause applies only to formalized testimonial materials, but deeming this report sufficiently formalized to fall within its purview. ${ }^{25} 131$ S Ct 2705 (2011).

${ }^{26}$ Prior to Melendez-Diaz, the New Mexico Supreme Court had held that blood alcohol reports were not testimonial. State v Dedman, 102 P3d 628 (NM 2004).

${ }^{27}$ State v Bullcoming, 226 P3d 1, 4 (NM 2010).

${ }^{28}$ New Mex Rule Evid 11-703 provides, "If of a type reasonably relied upon by experts in the particular field in forming opinions or inferences upon the subject, the facts or data need not be admissible in evidence in order for the opinion or inference to be admitted.”

${ }^{29}$ See FRE 701 and FRE 702.
} 
outside of the courtroom). The New Mexico Supreme Court reasoned that under this rule, it was legitimate for the testifying expert to have relied upon the information contained in the report by the absent expert. The testifying expert might not have conducted the specific test, but he knew the procedure well, and under the evidence rules, could therefore rely on the data contained in the absent expert's report in shaping his conclusion.

The New Mexico court did not probe this argument very deeply. The difficulty is that it is well established that one expert cannot simply "parrot" or serve as the mouthpiece for another, absent expert. ${ }^{30}$ So if the testifying expert were simply parroting the absent expert, gesturing to Rule 703 does not suffice. ${ }^{31}$ Moreover, under New Mexico's rather idiosyncratic interpretation of its own evidence rules, its version of Rule 703 does not permit an expert to rely upon the "opinion" of another expert but extends only to "facts or data." 32 The court endeavored to finesse these issues by insisting that the results of the gas chromatograph machine reported by the absent witness "do not constitute expert opinion," but rather, are simply facts and data upon which another expert could rely, since the absent expert was merely the "scrivener" for the machine data. $^{33}$

The Supreme Court rejected the prosecutor's effort to substitute a surrogate witness unconnected to the specific test at issue for the actual forensic tester. Even if another laboratory employee was very familiar with the testing process, the Court determined that the surrogate could not provide the defendant with the same opportunity to probe the specifics of the test as performed in this instance based on first-hand knowledge. Although the Court granted that the analyst who did the testing might lack any recall of the specific test, it still thought this distinction mattered. Presumably, the distinction is that a surrogate could not possibly have any first-hand recall because he was not there, whereas the actual analyst could in principle have recall, even though in practice he might frequently (and understandably, given both the routine and frequent nature of such tests and the passage of time between test and trial) not remember. More generally, the Court emphasized that a surrogate cannot provide the defendant with the same opportunity to probe the actual analyst's competence, veracity, and work habits. The point was especially salient in Bullcoming given that the actual analyst was on administrative leave for unknown reasons. At bottom, even a surrogate witness capable of explaining the test, the results, and the general operation of the machine is not good enough for the Constitution: "the Clause does not tolerate dispensing with confrontation simply because the court believes that questioning one witness about another's testimonial statement provides a fair enough opportunity for cross-examination."34 "Fair enough" is not fair enough for the Constitution.

\footnotetext{
${ }^{30}$ To be sure, the line between legitimately relying on information provided by others and illegitimately serving as a mouthpiece for their conclusions is not always clear. For a case at the borderland, see Dura Automotive Systems of Indiana Inc v CTS Corp, 284 F3d 609 (7th Cir 2002).

${ }^{31}$ See David H. Kaye, David E. Bernstein and Jennifer L. Mnookin, The New Wigmore-A Treatise on Evidence: Expert Evidence §§ 4.6.1(c), 4.7.1 (Aspen 2d ed 2011).

32 See State v Aragon, 225 P3d 1280 (NM 2010), cited in the State Supreme Court's opinion in Bullcoming. The cases cited in Aragon do not obviously support this idiosyncratic reading of Rule 703, but that is not our concern here. We simply note that the Advisory Committee to Rule 703 explicitly envisions the rule enabling experts to rely, at least in some circumstances, on the opinions and inferences of others, if they otherwise meet the rule's requirements, such as doctors relying upon the opinions of specialists. See Advisory Committee Note, FRE 703.

${ }^{33}$ Bullcoming, 226 P3d at 10.

${ }^{34}$ Bullcoming v New Mexico, 131 S Ct 2705, 2716 (2011).
} 
Justice Ginsburg's majority opinion also brushed aside the New Mexico Supreme Court's "mere scrivener" argument. The majority noted that the report contained statements that went beyond simply reporting a machine result, including assertions (explicit or implicit) that a prescribed protocol had been followed and that no unusual test circumstances affecting validity were present. ${ }^{35}$ The majority opinion simply ignored without comment the state court's argument that the surrogate could legitimately rely upon the absent witness's report to inform his own expert opinion.

Like Melendez-Diaz, Bullcoming was a 5-4 decision, and this majority was both awkwardly cobbled together and tenuous. Only Justice Scalia joined Justice Ginsburg's opinion in full. Justices Kagan, Sotomayor, and Thomas joined only portions. Justice Kennedy dissented again, expressing continued irritation with Melendez-Diaz, exasperation at its extension in this case, and doubts about whether Crawford itself was an improvement over the Ohio $v$ Roberts regime. Requiring testimony of the actual analyst in a case like this was, he said, a "hollow formality."36

In addition, Justice Sotomayor wrote a concurring opinion highlighting just how narrow the decision was. She succinctly laid out four still-open issues, one of which was the intersection of the Confrontation Clause and Rule 703. ${ }^{37}$ Citing Rule 703-hers was the only opinion to do so-she wrote:

This is not a case in which an expert witness was asked for his independent opinion about underlying testimonial reports that were not themselves admitted into evidence. ... [T]he State does not assert that [the testifying expert] offered an independent, expert opinion about Bullcoming's blood alcohol concentration. ... . We would face a different question if asked to determine the constitutionality of allowing an expert witness to discuss others' testimonial statements if the testimonial statements were not themselves admitted as evidence. $^{38}$

Soon enough, the Supreme Court faced that question. Last summer, in Williams, the prosecution finally found a winning combination of facts. Facing a backlog of DNA samples, the Illinois State Police laboratory (ISP) had shipped vaginal swabs and a sample of blood from a rape victim (L.J.) to Cellmark Diagnostics, a private laboratory in Maryland. Cellmark analysts performed a series of procedures to find certain distinctive features in semen in the swab. These included extracting DNA from the swabs and blood, making millions of copies of identifying fragments of the DNA (called "STR alleles"), producing graphs that indicated the lengths of the fragments, and comparing the sets of length measurements from the blood and vaginal swabs to infer which one came from the rapist ("mixture deconvolution"). ${ }^{39}$ Cellmark then wrote up a report about what they had found, and sent it back to the ISP.

\footnotetext{
${ }^{35}$ Id at 2715.

${ }^{36}$ Id at 2724 (Kennedy dissenting).

${ }^{37}$ The others were (1) when the evidence was produced not only for future use as testimony but also for some alternate purpose; (2) when the testifying witness was a supervisor or a reviewer who had some degree of first-hand connection to the actual test, even if he or she was not the primary analyst; and (3) when the State truly introduced only machine-generated results like a gas chomatograph. Id at 2722 (Sotomayor concurring).

${ }^{38}$ Bullcoming, $131 \mathrm{~S}$ Ct at 2722.

${ }^{39}$ See David H. Kaye and George Sensabaugh, Reference Guide on DNA Evidence, in Reference Manual on Scientific Evidence 129 (National Academies 3d ed 2011).
} 
The state did not try to introduce the report submitted to the ISP into evidence. Nor did the state call anyone from Cellmark to testify about what that laboratory had done or what results it had found. Instead, the prosecution called a former ISP analyst named Sandra Lambatos who had studied the report, then checked the state's offender DNA database, and found one matching man. She opined, in effect, that this man-Sandy Williams-was a source of DNA on the vaginal swab that had been analyzed by Cellmark. ${ }^{40}$

The prosecution insisted that it was introducing this witness's references to Cellmark's testing only to show the basis for her own expert conclusions about the database match to Williams. "I'm not getting at what another lab did," the prosecutor assured the court. ${ }^{41}$ The only reason for the ISP analyst's testimony, the prosecutor maintained, was to establish that she found a match in the database. ${ }^{42}$ However, the prosecutor actually went one step further. Despite her representations to the court, she framed a question that referred, awkwardly, to Cellmark's conclusions: "Was there a computer match generated of the male DNA profile found in semen from the vaginal swabs of [L.J.] to a male DNA profile that had been identified as having originated from Sandy Williams?"43 To which Lambatos answered, "Yes, there was." 44

The appellate courts in Illinois saw no problem in this maneuver. Because the report was not formally offered for its truth, but only to provide a basis for the testifying expert's opinion about the source of the DNA on the swab, these courts thought the confrontation problem evaporated. After all, they explained, Crawford explicitly noted that its exclusionary rule does not apply when testimonial statements are introduced for some purpose other than establishing "the truth of the matter asserted" (TMA). ${ }^{45}$ They saw the case as equivalent to a laboratory supervisor or director testifying to her own probability calculations based on the "bench work" of

${ }^{40}$ See Joint Appendix, Williams v People of the State of Illinois, No 10-8505, *57-58 (filed Aug 31 2011) ("Joint Appendix") (available on Westlaw at 2011 WL 3873378):

Q In other words is the semen identified in the vaginal swabs of [L.J.] consistent with having originated from Sandy Williams?

A Yes.

Q What is the probability of this profile occurring in the general population?

...

THE WITNESS: This profile would be expected to occur in approximately 1 in 8.7 quadrillion black, 1 in 390 quadrillion white, or 1 in 109 quadrillion Hispanic unrelated individuals.

Q Do you know the approximate population of the world?

A Approximately 6 billion.

MR. WALSH: Objection.

THE COURT: Overruled.

MS. PETRONE: Q In your expert opinion, can you call this a match to Sandy Williams?

A Yes.

${ }^{41}$ Id at *56.

42 "I was referring to a computer data base without saying any more about that but after she received that information for the data base she did her own testing based on that information.” Id.

${ }^{43}$ Id. Before sending the samples to Cellmark, ISP staff had ascertained that semen were present in the vaginal swab. After sending them, it took and analyzed a DNA sample from Williams in an unrelated case. The two technicians who performed these actions testified at William's trial.

${ }^{44}$ Joint Appendix at *56.

${ }^{45}$ People v Williams, 939 NE2d 268, 277 (Ill 2010) citing Crawford v Washington, 541 US 36, 59 n 9 (2004), affd Williams v Illinois, 132 S Ct 2221 (2012). 
other employees even when those employees do not testify-a practice that the Illinois Supreme Court approved in 2006. ${ }^{46}$

The prosecution's fancy footwork in Williams stimulated four opinions-none of which commanded a majority. A majority did vote to affirm the conviction, but not on the Illinois courts' no-TMA theory. The strongest support for that theory came in an opinion written by Justice Alito. This opinion emphasized that "[i]t has long been accepted that an expert witness may voice an opinion based on facts concerning the events at issue in a particular case even if the expert lacks first-hand knowledge of those facts." $" 7$ Justice Alito also pointed out that the prosecution could have asked the ISP analyst a hypothetical question with the content of the Cellmark report as its premise. ${ }^{48}$ Then he explained that Federal and Illinois Rule of Evidence 703 goes one step further: "an expert may base an opinion on facts that are 'made known to the expert at or before the hearing,' but such reliance does not constitute admissible evidence of this underlying information." 49 The underlying information is admissible, not for its truth, but only for "the legitimate nonhearsay purpose of illuminating the expert's thought process." ${ }^{50}$ Hence, it was fine for the analyst who had no connection to Cellmark to answer the prosecution's question about Cellmark's findings.

In addition to divining this supposedly "legitimate nonhearsay purpose," this opinion deemed dispositive the fact that the report was not "prepared for the primary purpose of accusing a targeted individual." ${ }^{51}$ Because there was as yet no suspect in the case, "the primary purpose of the Cellmark report, viewed objectively, was not to accuse petitioner . . .."52 The opinion thus sought to confine the Confrontation Clause to statements made to accuse not just someone, but someone in particular. But Justice Alito made this argument largely in passing; it is the no-TMA argument that receives the most attention and care, and upon which we will focus. ${ }^{53}$ Chief Justice Roberts and Justices Kennedy and Breyer signed on, although a separate opinion by Justice Breyer retreated slightly on the no-TMA reasoning. ${ }^{54}$

Another foursome, led by Justice Kagan, was incredulous. "Have we not already decided this case?," they asked. ${ }^{55}$ As they saw it, the witness's testimony was "functionally identical to the 'surrogate testimony' that New Mexico proffered in Bullcoming, which did nothing to cure

${ }^{46}$ Williams, 939 NE2d at 275, citing People v Sutherland, 860 NE2d 178 (Ill 2006).

${ }^{47}$ Williams, $132 \mathrm{~S}$ Ct at 2233 (Alito) (plurality).

${ }^{48}$ Id at 2234.

${ }^{49}$ Id at 2235.

${ }^{50}$ Id at 2240 (emphasis added).

${ }^{51}$ Williams, 132 S Ct at 2243.

${ }^{52}$ Id.

${ }^{53}$ On the "no-accusation" theory, see Kaye, et al., Expert Evidence § 4.12.8 (Supp, 2012) (cited in note *) (concluding that "While a focus on whether evidence is accusatory might provide a valuable lens for exploring the . . c category of the "testimonial," the plurality opinion in Williams does not provide enough specificity to make the category workable, nor does it offer a satisfying defense of its definitions and categories."). See also note 67.

${ }^{54}$ Justice Breyer wrote that in permitting the putative nonhearsay use, the federal and Illinois rules of evidence are "artificial.” Id at 2246 (Breyer concurring). To ensure that the Confrontation Clause is not read to require the presence of every technician associated with a laboratory test, he would have preferred to rehear the case facing more directly and more broadly how the Confrontation Clause should apply to crime laboratory reports, perhaps with an eye to overturning or modifying Bullcoming and MelendezDiaz. Williams, 132 S Ct at 2244, 2248 (Breyer concurring).

${ }^{55}$ Williams, $132 \mathrm{~S}$ Ct at 2264, 2267 (Kagan dissenting). 
the problem identified in Melendez-Diaz (which, for its part, straightforwardly applied our decision in Crawford )." "56 These Justices scorned the theory of the Illinois courts that Cellmark's statements (whether or not true) were mentioned solely for the allegedly nonhearsay purpose of helping the factfinder understand the ISP expert's conclusions about a database match. Writing for herself and Justices Scalia, Ginsburg, and Sotomayor, Justice Kagan called "the idea that such 'basis evidence' comes in not for its truth, but only to help the factfinder evaluate an expert's opinion 'very weak,' 'factually implausible,' 'nonsense,' and 'sheer fiction..”57

Justice Thomas agreed with these Justices that the no-TMA theory was implausible and the "targeted individual” requirement groundless. "There is," he wrote in a separate opinion, "no meaningful distinction between disclosing an out-of-court statement so that the factfinder may evaluate the expert's opinion and disclosing that statement for its truth." ${ }^{58}$ Nevertheless, he added his vote to those of the Alito plurality "solely because Cellmark's statements lacked the requisite 'formality and solemnity' to be considered 'testimonial' for purposes of the Confrontation Clause." ${ }^{59}$ So at the end of the day, there were three arguments in support of the holding: (1) that the statements were not offered for the truth of the matter asserted; (2) that the statements were insufficiently formalized to count as testimonial; and (3) that the statements were not accusatory. But not one of them mustered a majority; and they push in different directions in terms of what statements ought to be excluded as testimonial.

It is also worth noting that in Williams, it was Justice Breyer who was most explicitly arguing for a form of science exceptionalism under the Confrontation Clause, in terms similar to those offered by Justice Kennedy in Melendez-Diaz. Justice Breyer noted that "the need for cross-examination is considerably diminished when the out of court statement was made by an accredited laboratory employee operating at a remove from the investigation in the ordinary course of professional work," because "alternative features of such situations help to guarantee its accuracy," like professional guidelines, standards, and documentations norms. ${ }^{60}$ Crossexamination of the actual expert is a less effective check on accuracy, in his view, then the structural mechanisms operating within science itself-though, to be sure, in Crawford and Melendez-Diaz, the majority opinions made clear that reliability was not to be understood as either the purpose or the lodestar of the Confrontation Clause.

This overview of the new trilogy has endeavored to describe the development of the Confrontation Clause as it affects laboratory reports and to show how the lurking question of science exceptionalism has made these cases difficult to resolve. One set of Justices has been prepared to apply the logic of Crawford across all kinds of witnesses equally, seeing no justification for carving out a different approach to forensic science. They emphasize that reliability is not a substitute for confrontation - and after all, a turn away from reliability was the key contribution of Crawford - and also point out that forensic science is far from foolproof and cannot simply be presumed reliable. Another group of Justices cannot fathom that a laboratory

\footnotetext{
${ }^{56} \mathrm{Id}$.

${ }^{57}$ Id at 2269 (quoting Kaye, et al, Expert Evidence § 4.10.1, at 196-97 (cited in note 31); id § 4.11.6, at 24 (Supp. 2012)).

58 Id at 2255, 2257 (Thomas concurring). Justice Thomas added that "[t]o use the inadmissible information in evaluating the expert's testimony, the jury must make a preliminary judgment about whether this information is true.” Id (quoting Kaye, et al, Expert Evidence § 4.10.1, at 196 (cited in note 31)).

${ }^{59}$ Id at 2255 (Breyer concurring).

${ }^{60}$ Id at 2250.
} 
technician, doing his ordinary, routine job guided by standard operating procedures and protocols, who has probably never seen the defendant and, unless he testifies, in all likelihood never will, belongs in the same analytic box under the Confrontation Clause as someone making a statement to the police or undergoing interrogation.

From a certain point of view, Justice Alito’s no-TMA argument is remarkably clever. A strong but plausible version of the no-TMA argument would provide a way for experts formally to remain subject to the Confrontation Clause's strictures just like any other witnesses, but practically speaking, it would permit prosecutors a good deal of flexibility. If a testifying expert can rely upon-and even disclose, albeit (allegedly) not for its truth—a testimonial report by a nontestifying expert, then the Court would be building a certain degree of scientific exceptionalism into the Confrontation Clause through Rule 703. Rather than exempting scientific experts wholesale, as the dissent in Melendez-Diaz seemed to desire, it would use the existing evidence rules to ensure that practically speaking, the Confrontation Clause had little bite. $^{61}$

It is therefore worth considering carefully the competing arguments regarding the noTMA theory. ${ }^{62}$ We show that in the setting of Williams, the theory is ultimately implausible but that in other settings, it could have more traction. Rule 703, properly understood, should be neither the open ticket to admission that some state courts have been buying ${ }^{63}$ nor the simple formalism depicted in the plurality opinion in Williams. We begin the next section by briefly asking why the Confrontation Clause only applies to statements introduced for their truth. We then consider two explanations for why the statements in Williams were offered for their truth. Both explanations appear in the opinions of Justices Thomas and Kagan in Williams, but they are intertwined. Untangling them helps show why the no-TMA theory fails in Williams but might succeed elsewhere. Finally, we briefly discuss the future of laboratory reports under the Confrontation Clause.

\section{Williams, RUle 703, AND THE TRUTH OF THE MATTER AsserTed}

In Williams, the entire Court assumed that TMA is an essential element of the right to confrontation. But not a single opinion in Williams - or Crawford, in which the Court slipped the thought inside a single parenthetical sentence inside a footnote-explains why. ${ }^{64}$ The most plausible answer stems from the perception of Justice Alito's plurality that an accuser is central to the clause. As Justice Scalia wrote in Coy $v$ Iowa, ${ }^{65}$ the clause encapsulates the image painted

${ }^{61}$ On the dangers of "stealth" testimonial hearsay under Rule 703, see generally Julie A. Seaman, Triangulating Testimonial Hearsay: The Constitutional Boundaries of Expert Opinion Testimony, 96 Georgetown L J 827 (2008).

${ }^{62}$ For a related, but broader treatment of the many theories in the case, see Kaye, et al, Expert Evidence $\S$ 4.12 (Supp. 2013) (cited in note 31).

${ }^{63}$ Pendergrass v State, 913 NE 2d 703 (Ind. 2009); State v Crager, 879 NE 2d 745, 758 (Ohio 2007).

${ }^{64}$ Crawford, 541 US at $59 \mathrm{n} 9$.

65487 US 1012 (1988). In Coy the trial court used a screen to block a man charged with sexually assaulting two thirteen-year-old girls from the sight of the girls as they testified. Justice Scalia wrote for the majority of the Court in holding that the barrier violated defendant's right to face-to-face confrontation. In Maryland v Craig, 497 US 836 (1990), the Court retreated from Coy's seemingly per se rule requiring face-to-face confrontation. Justice O'Connor wrote for the majority, ruling that the Confrontation Clause merely embodies a "preference" for face-to-face, in-person confrontation, which 
by Shakespeare "when he had Richard the Second say: 'Then call them to our presence-face to face, and frowning brow to brow, ourselves will hear the accuser and the accused freely speak." " 66 With this animating principle in mind, the domain of the Clause should be confined to statements that are not merely testimonial but also accusatorial. ${ }^{67}$ A statement may have been intended to accuse someone of criminal misconduct, but if it is not being used that way at trial, then there is no accuser who needs to be confronted. More generally, if the prosecutor is not asking the factfinder to credit the out of court statement, to consider it to be true, then the veracity, the perceptual abilities, and the memory of the out-of-court speaker are irrelevant, or at least a good deal less important. ${ }^{68}$ Therefore, whether the statement of the absent "accuser" is introduced for its truth should matter. Indeed in Williams, while the Justices attacked each others' positions on whether the evidence was TMA with vehemence and vitriol, ${ }^{69}$ that the Confrontation Clause applied only to evidence offered for its truth was simply taken for granted by all sides.

\section{A. IF NOT TRUTH, THEN WHAT?}

Before turning to the specific forms of argument Justice Alito's plurality opinion offers in defense of its no-TMA position, it is worth noting there is nothing novel about the general argument that expert basis evidence is not offered for the truth of its contents. In fact, well before this set of Crawford-derived conundrums arose, many lower courts had taken an acrossthe-board position that an expert's disclosure of such evidence to the factfinder is not for the truth of its contents, but rather for the limited, nontruth purpose of helping the factfinder evaluate the adequacy of the expert's basis evidence by illuminating the expert's thought process. ${ }^{70}$ According to this argument, the purpose of telling the factfinder about the materials, data, or opinions upon which the expert has relied is not to have the factfinder accept any of this underlying material as true, but merely to assist the factfinder in assessing the credibility of the expert. The theory is that the factfinder can assess whether the expert has an adequate basis for the conclusions offered without substantively assessing whether this basis is actually true.

The difficulty with this argument is that to evaluate meaningfully the adequacy of the expert's basis, the factfinder-let us assume a jury, but the point applies equally to bench trials-

may be limited to satisfy sufficiently important interests. Applying this balancing test, the Court held that the Confrontation Clause did not bar the use of one-way closed-circuit television to present testimony by an alleged child sex abuse victim when the trial court found that the child was reportedly unable to testify in the physical presence of the defendant due to severe emotional trauma.

${ }^{66}$ Id at 1016.

${ }^{67}$ Following Crawford, but prior to Melendez-Diaz, numerous courts attempted to bracket some or all forensic science evidence as nontestimonial with the notion that the Confrontation Clause applied only to accusatorial evidence. See Mnookin, 15 J L \& Pol at 847-50 (cited in note 13); Robert P. Mosteller, "Testimonial" and the Formalistic Definition-The Case for an "Accusatorial” Fix, 20 Crim Just 14 (Summer 2005). The Williams plurality tried to revive this notion, but with an uncomfortably cramped conception of what makes a statement accusatorial.

${ }^{68}$ For the classic analysis of the "hearsay" dangers and an explanation for why hearsay is limited to TMA, see Lawrence H. Tribe, Triangulating Hearsay, 87 Harv L Rev 957 (1974).

${ }^{69}$ Justice Alito's plurality opinion condemns the reasoning of the dissent as "truly remarkable," $132 \mathrm{~S} \mathrm{Ct}$ at 2237, and "a very clear error.” Id at 2239 (Alito) (plurality). Justice Kagan's dissent derides the plurality's at exposition as "a simple abdication to state-law labels" and "a neat trick—but really, what a way to run a criminal justice system.” Id at 2272 (Kagan dissenting).

${ }^{70}$ For a detailed look at this issue, see Mnookin, $15 \mathrm{~J} \mathrm{~L} \mathrm{\&} \mathrm{Pol} \mathrm{at} \mathrm{811-27} \mathrm{(cited} \mathrm{in} \mathrm{note} \mathrm{13).}$ 
must usually make a preliminary judgment about whether the information upon which the expert has relied is true. Much of the time, if the jury believes the expert's basis is true, it will also believe that the expert's reliance upon the basis is justified; conversely, if it doubts the truth of the expert's basis, it will likely doubt the legitimacy of the expert's reliance. But there are some situations in which one might be able to use the expert's basis evidence for credibility purposes without making a judgment about its truth. If the jury believes that the expert's basis evidence, even if true, is inadequate to support the expert's conclusions, then disclosure can assist the jury without necessitating a preliminary determination of the truth of that basis evidence. Or if other evidence in the record establishes the truth of the basis evidence, then the jury need not rely on the expert's disclosure in order to evaluate the adequacy of the basis evidence as grounds for the expert's conclusion. (We will come back to this point below.) Most of the time, however, it is simply not plausible to imagine that a factfinder, even a judge, can assess whether the expert's basis is adequate to support the expert's conclusion without also assessing-or, perhaps more accurately, often simply assuming - that basis's truth. Doing so would require reasoning like the following:

I am being asked whether the expert's basis is adequate to support his conclusion. I believe that the basis evidence detailed by the expert does, in theory, provide enough good grounds to support his conclusion, if the basis is itself accurate. However, I cannot consider the disclosure by the expert as proof of the basis's accuracy, because I cannot consider the basis evidence to be offered for the truth of the matter asserted. So all I can do is say that if the basis evidence were true, it would provide an adequate basis for the expert. I also know that the expert himself has relied on this basis-that is why it is being disclosed to me. Hence, the expert himself believes that the basis evidence is worth relying upon, and indeed, is true. But I cannot consider it to be true just because he does - that would still be taking its disclosure to me as helping to establish its truth, and I am prohibited from doing that. I am permitted, however, to defer to his conclusion, and the fact that he has relied upon a basis that would, if true, warrant his conclusion contributes to my willingness to believe his opinion is warranted. Still, I have no opinion-because I have no admissible evidence upon which to ground an opinionabout whether the basis evidence is actually true.

Granted, this inferential chain is logically possible. But it is incredibly formalistic and wildly implausible as a matter of human reasoning. ${ }^{71}$ Even if jurors are given limiting instructions, it is hard to believe that they will not take the expert disclosure (and the fact of expert reliance) as providing some degree of evidentiary support for the basis itself. Nor is it plausible to believe that judges could altogether avoid doing so either. The notion that factfinders will not consider the truth of the basis evidence when assessing the credibility of the expert who has relied on this evidence is, quite simply, a legal fiction.

Prior to Crawford, the not-for-the-truth argument solved an otherwise awkward problem for the courts. Rule 703 permits both reliance, and to some extent, disclosure of otherwise inadmissible evidence-usually hearsay. But what was the status of this inadmissible evidence? Rule 703 does not present itself as an exception to the hearsay rule. Certainly, it is not one of the many exceptions enumerated in Rules 803 and 804. ${ }^{72}$ Moreover, if experts' disclosures were

\footnotetext{
${ }^{71}$ For more detailed versions of this argument, see generally id; Kaye, et al, Expert Evidence §§ 4.7.2, 4.10.1 (cited in note 31).

${ }^{72}$ See generally FRE 803 and FRE 804.
} 
permitted for the truth of their contents, it could lead to parties' funneling substantial quantities of otherwise inadmissible evidence in through their experts. ${ }^{73}$ By attributing a nontruth purpose to the basis evidence, courts reduced the incentive for such funneling, for the matters disclosed by experts, being substantively inadmissible, could not help establish the sufficiency of any element and could not be advanced as true in a closing argument.

In addition, then as now, a nontruth purpose avoided thorny Confrontation Clause issues. Since Rule 703 is not, formally, a hearsay exception at all and is of rather recent vintage, it could not be considered a firmly-rooted hearsay exception. So if Rule 703 disclosures in the Roberts reliability era were made for their truth, then courts would have had to determine particularized indicia of reliability in every case. Given how little import the Confrontation Clause had in general in this period with respect to hearsay, for it to apply so strictly in the expert context seemed anomalous. Experts were only supposed to be able to rely upon materials "of a type reasonably relied upon by experts in the particular field," ${ }^{74}$ and at least arguably, this in conjunction with other rules regulating experts provided as much structural assurance for the reliability of an expert's basis as exists for many hearsay exceptions. In addition, much expert basis evidence could, in fact, be admissible with a little bit of rigmarole. Rule 703 therefore often operated as a shortcut to disclosure, rather than as a rule permitting disclosure of materials that were actually barred. Overall, then, prior to Crawford, the notion that such evidence was introduced for the allegedly nonhearsay purpose of helping the factfinder better understand and evaluate the expert's reasoning may have been a legal fiction, but it was a legal fiction that was largely of a piece with the broader approach to the Confrontation Clause.

Crawford and its progeny brought about three changes relevant to what we might term the Rule 703 compromise. First, reliability was no longer the critical conceptual category for determining the applicability of the Confrontation Clause-so if the Rule 703 compromise was implicitly predicated upon a sense that expert evidence had structural protections for reliability equivalent to firmly-rooted hearsay exceptions, this theory of reliability no longer made a difference. Second, the Crawford line of cases substantially expanded the Confrontation Clause's power and reach. Hence, if the Rule 703 compromise stemmed from a reluctance to apply the Clause forcefully to expert basis evidence given how little wingspan it had elsewhere, well, its wingspan had significantly expanded. Third, prior to Crawford, the dominant reason for expert basis evidence inadmissibility was that it was hearsay. It was inadmissible because of a rule of evidence, not because of the Constitution.

It is certainly not obvious that Rule 703 should apply in the same way when the reason for the basis evidence's inadmissibility is a constitutional protection. As we have seen, using the information strictly for a purpose other than its truth usually demands a mental dexterity to which human factfinders can only aspire. The rules of evidence ask them to try their best. When jurors are involved, the judge must caution the jury against relying on the basis statements for their truth, but there is little reason to believe this will be effective. When a judge is the factfinder, we may hope that professional exposure to the nuances of hearsay law will permit the

\footnotetext{
${ }^{73}$ Some commentators viewed this as such a substantial risk that they advocated prohibiting experts from disclosing their basis evidence altogether unless it was otherwise admissible. See, for example, Ronald I. Carlson, Policing the Bases of Modern Expert Testimony, 39 Vand L Rev 577 (1986). By contrast, others advocating permitting basis evidence to be used substantively, in essence operating as a hearsay exception. See, for example, Paul R. Rice, Inadmissible Evidence as a Basis of Expert Opinion Testimony: A Response to Professor Carlson, 40 Vand L Rev 583, 587 (1987).

${ }^{74}$ FRE 703.
} 
judge to compartmentalize his thinking, but even this may be unrealistic. ${ }^{75}$ We hope for the best (and tolerate the worst) because expert opinions (even when based partly on hearsay) are thought to have enough value to justify their admission. Nevertheless, even though we tolerate the Rule 703 compromise when basis evidence is not testimonial, it is not clear we should rely on pious hopes to safeguard a constitutional right.

In the years following Crawford, a few courts began to recognize the fictional quality of the not-for-the truth argument and therefore began to disallow disclosure of expert basis evidence when it consisted of seemingly testimonial statements from declarants not produced for cross-examination. ${ }^{76}$ But many courts chose instead to adhere mechanically to the Rule 703 compromise, and concluded, often with virtually no analysis, that experts can disclose what otherwise would be testimonial statements as mere basis evidence so long as it meets the requirements of Rule 703 (and, for some courts, so long as the testifying expert is doing something beyond mere parroting of the absent expert's concusions). These courts-including the Illinois courts in Williams-reasoned that this disclosure does not implicate the Confrontation Clause since the evidence technically was not being offered for its truth. ${ }^{77}$

\section{1. "Illumination" as a Nontruth Purpose in Williams}

This, then, was the lay of the land that the Supreme Court confronted in Williams. Justice Alito's plurality opinion accepts the broad pre-Crawford Rule 703 theory that basis evidence can be used for the non-substantive purpose of helping the judge or jury understand and evaluate the expert's opinions - while suspending all judgment on the truth of the basis evidence. Presuming that the trial judge followed the formal logic of Rule 703, the plurality maintained that the trial judge decided that Cellmark correctly characterized the DNA in the samples not because Cellmark prepared a report saying as much, but because of "circumstantial evidence."78 This evidence included the ISP's repeated assurances that the Cellmark lab was accredited, the fact that the ISP often used the outside lab to cope with its backlog, and that the victim implicitly confirmed the DNA match by picking a man with the same DNA type from a lineup. ${ }^{79}$

The majority of the Justices - four of them in the dissent penned by Justice Kagan and one more in the concurring opinion of Justice Thomas-found this construction of the trial court's reasoning unpersuasive at best. Most human beings, we have suggested, do not reason in so well-compartmentalized a manner, and the majority of the Court adopted the realist position

${ }^{75}$ See, for example, Andrew J. Wistrich, et al, Can Judges Ignore Inadmissible Information: The Difficulty of Deliberately Disregarding, U Pa L Rev 1252 (2005).

${ }^{76}$ See, for example, People v Goldstein, 843 NE 2d 727 (NY 2005); Vann v State, 229 P. 3d 197 (Alaska Ct App 2010).

${ }^{77}$ See, for example, State v Lyles, 615 SE 2d 890 (NC Ct App 2005); People v Thomas, 130 Cal App 4th 1202 (2005), United States v Mirabel, 2010 US Dist LEXIS 91595 (D NM). For more thoughtful preWilliams efforts to assess the relationship between expert basis evidence, hearsay, and expert disclosure under the Confrontation Clause, see, for example, United States v Pablo, 625 F 3d 1285 (10th Cir 2010); People v Hill, 191 Cal App 4th 1104 (2011).

${ }^{78} 132 \mathrm{~S} \mathrm{Ct}$ at $2237 \mathrm{n} 7$ ("[B]ecause there was substantial (albeit circumstantial) evidence on this matter, there is no reason to infer that the trier of fact must have taken [the ISP analyst's] statement as providing "the missing link.").

${ }^{79}$ Although the plurality opinion regarded that as a tremendous coincidence in the absence of guilt, the lineup was conducted more than a year after the attack, and it was no coincidence that a man-the defendant—with the incriminating DNA type was in the lineup. 
that Rule 703 basis evidence is likely to be used for its truth regardless of the formal logic that undergirds the rule. In response, the plurality indignantly dismissed the dissent's legal realism as constituting "a profound lack of respect for the acumen of the trial judge." 80

However, speculation or presumptions about how the trial judge reasoned are immaterial to a narrower argument against the formal logic of Rule 703 in this setting. The argument is not necessarily that the psychology of Rule 703 is grossly unrealistic (though it may well be). It is that in this particular case, disclosure of Cellmark's role cannot be seen as serving "the legitimate nonhearsay purpose of illuminating the expert's thought process." 81 This, we believe, is the dominant, and stronger, strain of the Kagan-Thomas critique. It involves several subtleties that can be missed in the rapid-fire volleys back and forth in the Williams opinions. Consequently, we will explicate it some detail. We begin with Justice Alito's description of the expert's testimony:

She testified to the truth of the following matters: Cellmark was an accredited lab; the ISP occasionally sent forensic samples to Cellmark for DNA testing; according to shipping manifests admitted into evidence, the ISP lab sent vaginal swabs taken from the victim to Cellmark and later received those swabs back from Cellmark; and, finally, the Cellmark DNA profile matched a profile produced by the ISP lab from a sample of petitioner's blood. Lambatos had personal knowledge of all these matters, and therefore none of this testimony infringed petitioner's confrontation right.

Lambatos did not testify to the truth of any other matter concerning Cellmark. She made no reference to the Cellmark report, which was not admitted into evidence and was not seen by the trier of fact. Nor did she testify to anything that was done at the Cellmark lab, and she did not vouch for the quality of Cellmark's work. ${ }^{82}$

In this inventory of statements, one critical piece is missing, or at least passed over too quickly. Cellmark did not simply send back swabs to the ISP. It also sent back graphs and a table of DNA alleles it claimed to have generated from the semen found on those swabs. ${ }^{83}$ The ISP analyst testified that she relied on the graphs and the table from Cellmark-what Justice Alito calls "the Cellmark DNA profile" — to reach her own conclusion that the samples sent to Cellmark and the one taken from Williams matched. ${ }^{84}$ In addition, Ms. Lambatos implicitly but clearly offered a related opinion-that the information she received from Cellmark was trustworthy.

Although Justice Alito asserts that Lambatos did not vouch for the accuracy or quality of Cellmark's work, this depends on exactly what is meant by the word "vouch." She did not "vouch" for its accuracy based on personal involvement in the testing, for she acknowledged on cross-examination that she had nothing to do with that testing. But she clearly indicated that she trusted the outside laboratory to do reliable work, given its accredited status, its repeated work

\footnotetext{
${ }^{80}$ Id at 2237.

${ }^{81}$ Id at 2240.

${ }^{82}$ Id at 2235.

${ }^{83}$ In this case, the table of alleles did not correspond to only one possible DNA profile. See David $\mathrm{H}$. Kaye, Williams v. Illinois-Part II: More Facts, from Outside the Record, and a Question of Ethics, Forensic Science, Statistics and the Law Blog (Blogspot Dec. 15, 2011), online at http://for-sci-lawnow.blogspot.com/2011/12/williams-v-illinois-part-ii-more-facts.html (visited Jan 14, 2013). This ambiguity in the profile of the DNA in the semen affects the computation of random-match probabilities slightly, but the oversimplification is of no importance on the confrontation issue.

${ }^{84}$ This much was implicit in her testimony on direct examination, and the cross-examination made her reliance on the Cellmark report explicit.
} 
for the state, and, of course, her willingness to act on the information. ${ }^{85}$ Her testimony made clear both that she had relied upon Cellmark's information, and, that in her expert judgment, it was worthy of reliance.

Examined carefully, the record reveals not one, but three opinions offered by the expert about the DNA Cellmark provided to the ISP. Opinion 1 is that Cellmark's information attributing certain alleles to the semen found in L.J.'s vaginal swab is probably accurate. Opinion 2 is that those alleles match the defendant. Opinion 3 is that in all probability, they match no one else. Combining all these opinions produces a chain of reasoning culminating in the conclusion that Sandy Williams is the source of the semen. Only Opinion 1 poses a possible confrontation problem in the case because it is only here that the state's analyst relied on the work of another laboratory that was not presented by a witness who could be meaningfully cross-examined about that work.

Justice Alito endeavored to isolate and defang Opinion 1 by an analogy to a hypothetical question. According to the analogy, Cellmark's statements are a mere premise to the analyst's testimony, to be established by other evidence. If other evidence persuasively suggests that Cellmark's analysis is reliable, then it would be perfectly permissible to ask an expert a hypothetical question that assumed this other evidence as true. In other words, Justice Alito treated the expert's testimony as if she had testified "If I were to assume that the DNA profile of the semen is that given in Cellmark's report and then combine that assumed fact with my findings that this set of alleles is virtually unique and matches the alleles of Williams recorded in the database, then I would conclude that the semen came from Williams.” This we may call "premise-only" testimony, for the only role that Opinion 1 plays is that of the premise in the reasoning that attributes the semen to Williams. ${ }^{86}$

Construing Lambatos' testimony as premise-only testimony is vital to the plurality's noTMA theory because it makes it possible for the plurality at least to argue that the trial court did not rely on the analyst's beliefs about the quality of Cellmark's work. If other evidence supported a belief in the reliability of Cellmark's analysis, then crediting the judge with following Rule 703's strictures not to consider the truth of the basis evidence is at least plausible. However, the premise-only view of the testimony necessarily defeats the Rule 703 argument. Lambatos undertook what the prosecution called "her own testing" ${ }^{87}$ and what the trial court called her "own independent testing of the data received",88 only with regard to Opinions 2 and 3.

${ }^{85}$ For example, on cross-examination defense counsel asked, "You did not know if they observed or checked the calibration of their instruments—correct?" Lambatos replied: "Well, [Cellmark] Diagnostic is an accredited laboratory so they would have to meet certain guidelines to perform DNA analysis for the Illinois State police and so all those calibrations and internal proficiencies and controls would have had to have been in place for them to perform the DNA analysis.” Joint Appendix at 59-60.

${ }^{86}$ However, this case does not fit comfortably into the premise-only mold. We give an example of true premise-only testimony in the final section.

${ }^{87}$ See note 42.

${ }^{88}$ The trial court admitted what it understood to be the ISP analyst's "own independent testing of the data received from [Cellmark]." Joint Appendix at 93-94. At most, this means that she not only input the Cellmark numbers and found a database match to Williams, but that she also inspected the graphs to verify that the numbers that Cellmark attributed to the male part of the DNA mixture were those for DNA fragments within the DNA profile of someone other than L.J. Her views on the deconvolution of the mixture might have been admissible, but the prosecution did not ask about her thought process for mixture interpretation. It asked for her opinion on a match in the database. See text accompanying notes $41-42$. 
Under the theory for which her testimony was offered, Rule 703 would allow her to disclose the origin of the alleles she input into the computer-but only insofar as this information could affect the soundness of those opinions, and the Opinion 1 premise had no effect on those independent opinions. That is, Cellmark's work neither enhanced nor diminished the likely accuracy of her testimony that the computer found a match to the alleles she input and that this set of alleles was rare in the population (Opinions 2 and 3). Knowing that Cellmark fed her certain graphs and numbers explains why she typed those particular numbers, but this why sheds no light on the quality of the conclusion that William's database profile corresponds to the profile she input for her database query. It does nothing to illuminate how a computer makes a match, how the matching database record is linked to Sandy Williams, or how rare the matching features are in the population. And eliciting this latter set of explanations was the only ground the prosecution gave for calling the ISP analyst to the stand. ${ }^{89}$ Recall that the prosecution insisted "I'm not getting at what another lab did," but only asking the analyst about her own testing based on [DNA] information from Cellmark." 90 Under this quite delimited theory of what the testimony was provided for, disclosing her belief about the source of the DNA she analyzed simply does not illuminate her thought process vis-à-vis the methods of her own testing.

Under a less cramped theory of the purpose of the evidence, the ISP analyst's disclosure of Opinion 1 could indeed illuminate her thought process - but then, it would be running through a truth inference. As we have noted, Rule 703 permits experts to rely upon inadmissible evidence so long as it is of a kind that experts in the field would reasonably rely. It is probably reasonable for experts to rely on DNA analyses conducted by other accredited laboratories. So putting the Confrontation Clause to one side, under Rule 703, there would most likely be nothing impermissible about the ISP expert testifying to her ultimate conclusion that the DNA found in the vaginal swab matched the defendant, notwithstanding that this conclusion required reliance upon the accuracy of Cellmark's report. ${ }^{91}$ But notice: to reach that ultimate conclusion, the ISP analyst had to accept the truth of Cellmark's report. There is nothing wrong with a scientist engaging in that kind of epistemic deference to the findings of other trusted experts. The point is simply that the inferential chain for that ultimate conclusion necessarily runs through the truth of Cellmark's report. We see, then, that disclosing Opinion 1 to the jury neither strengthens nor weakens the expert's testimony with regard to Opinions 2 and 3. So Opinion 1 illuminates her thought process only insofar as it reveals that she also believes Opinion 1, and that belief undergirds her opinion that Williams' DNA was found in the vaginal swabs from the victim.

It is also worth noting that although Cellmark's findings revealed nothing about the quality of the ISP analyst's admissible conclusion that the alleles used in her database query produced a match to a profile with a negligible random-match probability (Opinions 2 and 3), there was a valid reason for the state to disclose the fact that Cellmark attributed the alleles to semen from Williams. Without some explanation of why Lambatos input the numbers she did, her actions are barely intelligible and would lack relevance. Evidence of this sort certainly can be admissible to complete the prosecution's story. ${ }^{92}$ But this source of illumination has no bearing

\footnotetext{
${ }^{89}$ See text accompanying notes 41-42.

${ }^{90}$ Williams, $132 \mathrm{~S}$ Ct at 2230.

${ }^{91}$ Indeed, this is an example of the kind of epistemic deference and distributed cognition that we discuss below, in Part III.

92 See, for example, 1 Kenneth Broun, ed, McCormick on Evidence $\S 190$ (West 7th ed 2013); compare Old Chief v United States, 519 US 172, 189 (1997) (addressing the argument that evidence of an earlier
} 
on the hearsay issue in Williams. It pertains to relevance, and relevance does not provide a way around the argument that the evidence is testimonial unless the evidence is legitimately offered for a non-TMA purpose. Evidence of prior criminal conduct, for example, sometimes is required for narrative integrity. When this occurs, the evidence is relevant for a purpose other than indicating a propensity to commit crimes, which helps overcome an objection to character evidence. ${ }^{93}$ Even in that situation, however, the background evidence is still introduced for its truth. If the proof of the missing part of the narrative is false, then the evidence has no probative value. $^{94}$

The notion that an assertion that has no probative value when it is false supplies a heuristic with which to test any argument about TMA. We simply ask whether the factfinder would have any use for the out-of-court statements if their truth value were altered. Consider Tennessee $v$ Street. ${ }^{95}$ The Crawford Court cited Street as establishing that only statements introduced for their truth can offend the Confrontation Clause, ${ }^{96}$ but the no-TMA majority in Williams easily distinguished the statements in Street from those in Williams. As Justice Thomas explained, in Street

the defendant testified that he gave a false confession because police coerced him into parroting his accomplice's confession. On rebuttal, the prosecution introduced the accomplice's confession to demonstrate to the jury the ways in which the two confessions differed. Finding no Confrontation Clause problem, this Court held that the accomplice's out-of-court confession was not introduced for its truth, but only to impeach the defendant's version of events. ${ }^{97}$

This reasoning is correct because in Street, even if we flip the truth value of the accomplice's confession, it still proves the prosecution's point - that the defendant was not coerced into saying the same thing as the accomplice. If the two confessions are the same, it provides some element of support for the defendant's claim. If they are substantially different, it weakens his argument-and this is true whether the accomplice's confession is entirely true, entirely false, or somewhere in between.

This invariance under an inversion in the truth value exists in some expert opinion cases as well. Consider Weber $v$ BNSF Railway Co. ${ }^{98}$ A train engineer felt ill after he was stuck in a tunnel with fumes from other locomotives. The treating physician testified that the employee had brain damage from acute carbon monoxide poisoning. Not only was that his initial diagnosis, but

crime should be admissible on the ground that "[p]eople who hear a story interrupted by gaps of abstraction may be puzzled at the missing chapters.”).

${ }_{93} 1$ McCormick $\S 190$ (cited in note 92).

${ }^{94}$ In some situations, evidence that completes the story is not hearsay. This occurs when an out-of-court statement truly is introduced solely for its effect on the hearer. A police officer sued for an illegal arrest can defend by showing that the arrest came after learning from an apparently reliable source that a warrant for the plaintiff's arrest was outstanding - even though the warrant had been quashed. Compare Arizona v Evans, 514 US 1 (1995) (declining to apply the exclusionary rule for unconstitutionally seized evidence in this situation). The probative value of the report of the outstanding warrant does not depend on its truth. True or false, the report establishes a good faith basis for the arrest.

${ }^{95} 471$ US 409 (1985).

${ }^{96}$ Crawford, 541 US 36, 59-60 n 9 (2004).

${ }^{97}$ Williams, $132 \mathrm{~S}$ Ct at 2256-57 (Thomas concurring) (citations omitted).

${ }^{98} 261$ P3d 984 (Mont 2011). 
he referred the patient to a neurologist who conducted a PET scan and reported to his primary physician that the scan indicated carbon monoxide poisoning. In Weber, one can at least argue that the physician's testimony that he had the neurologist do a PET scan is admissible independently of the truth of the neurologist's inferences-because it shows how thorough the physician was in making his diagnosis. Even if the PET scan had been inconclusive, the physician might have been able to defend his diagnosis (and show that he did everything he was supposed to do to make the diagnosis, so that his opinion should be believed). The nonhearsay logic would be that his care and conscientiousness in bringing in a neurologist revealed his thoroughness in gathering information for his diagnosis and in using all the data, including information from his examination of the patient and other sources independent of the neurologist. In an alternative world in which the physician made his conclusion about carbon monoxide poisoning with an inconclusive PET scan, the conclusion would not as strong as the one supported by the PET scan, but the disclosure of the inconclusive PET scan still would have relevance apart from its truth. Thus, changing the truth value of the neurologist's out-of-court statement about the PET scan affects only the weight the factfinder should accord the testifying physician's conclusion. If the physician's testimony with the weaker foundation is the only evidence of carbon monoxide poisoning, then a factfinder still might be able to credit it, and if so, the plaintiff's case should withstand a motion for a directed verdict. To be sure, in cases like this one, there might be a concern that the factfinder would take the corroborating PET scan as true, but at least there is a logical basis for arguing that the evidence would remain relevant even with a different conclusion, and hence it is not introduced solely for its truth.

The same nontruth reasoning does not work in Williams. If the prosecution wants the expert to give the limited opinion ostensibly desired in Williams — namely, that Williams is the only person whose DNA profile matches the alleles the analyst considered - then the prosecution has the previous problem of explaining how the expert's report that the alleles came from an unrelated laboratory that tested certain samples illuminates the thought process of going from those numbers to that conclusion. For that expert thought process, the Rule 703 rationale is inapposite. The analyst's reasoning that a set of numbers triggered a unique database match is neither stronger nor weaker depending on the source of the numbers. Had the numbers come to the analyst in a dream, or had she found them scrawled on her desk in an anonymous note, her reasoning from them to Sandy Williams would have been the same.

To make the situation analogous to Weber (and more like the hypothetical question envisioned in the plurality opinion), we must envision the analyst providing a different opinion. Suppose that the prosecutor in Williams had explained that her purpose in calling the ISP analyst was to have this expert opine not just that she found a database match to Williams, but also that some of the DNA on the swab came from Williams. Like the diagnosis of the physician in Weber, the DNA analyst's opinion then would rest on her own work (in the database matching and evaluation step) and on the preceding expert's information (in the prior step characterizing the rapist's DNA). Suppose that the court allows the expert to refer to Cellmark's testing solely to show the quality or nature of her reasoning from Cellmark's report to the revised conclusion that Williams is the source of the rapist's semen (what we designed as Opinions 2 and 3).

Now notice what happens when we change the truth content of the Cellmark's report from "true" to "inconclusive." The prosecution can hardly argue that relying on the statements in that report to initiate a database search makes the final conclusion about Williams any more believable than if the expert used the dream sequence of numbers. This is unlike the consultation with the neurologist in Weber, which could have supported the diagnosis even if the neurologist 
had made a mistake. So the evaluation of the quality of the expert's new final conclusion does depend on the TMA in the report. If Cellmark made a mistake, the probative value of input from Cellmark is not just reduced, but nonexistent. Try as we might, the Rule 703 nonhearsay logic does not work in the context of Williams. ${ }^{99}$

What we see, then, is that it would be too hasty to reject absolutely the plurality's noTMA theory for basis evidence. To conclude that the Rule 703 compromise is a legal fiction because, realistically, expert basis evidence is always disclosed for its truth goes too far. There are some limited instances like Weber, where if we modify the basis evidence, it still remains relevant to the expert's analysis. Such evidence is not hearsay and can be presented without violating the Confrontation Clause. But if the basis evidence is of no value to the prosecution unless it is true, as in the Williams case, then it cannot elude the Clause on the ground that it is not hearsay because it illuminates the expert's thought process.

\section{Hearsay and the Improbability Drive}

The plurality's discussion of TMA obliquely suggests another possible reason to treat the expert's reference to Cellmark's laboratory findings in Williams as nonhearsay and therefore beyond the reach of the Confrontation Clause. The plurality appears to find quite significant the fact that Cellmark returned a profile that happened to match someone in the database who then happened to be identified as the perpetrator by the victim in a lineup. Justice Alito wrote:

[T]here is simply no plausible explanation for how Cellmark could have produced a DNA profile that matched Williams' if Cellmark had tested any sample other than the one taken from the victim. . . . Thus, the fact that the Cellmark profile matched Williams - the very man whom the victim identified in a lineup and at trial as her attacker-was itself striking confirmation that the sample that Cellmark tested was the sample taken from the victim's vaginal swabs."100

${ }^{99}$ This difference between a valid use of Rule 703 and the one in Williams supports Justice Kagan's frustration with some of the plurality's analysis. She wrote that:

In responding to this reasoning, the plurality confirms it. According to the plurality, basis evidence supports the "credibility of the expert's opinion" by showing that he has relied on, and drawn logical inferences from, sound "factual premises." Quite right. And that process involves assessing such premises' truth: If they are, as the majority puts it, "unsupported by other evidence in the record" or otherwise baseless, they will not "allay [a factfinder's] fears" about an "expert's reasoning." I could not have said it any better.

Williams, 132 S Ct at 2269 n 1 (Kagan dissenting) (citations omitted).

Tenacious to a fault, however, our prosecutor might not give up on Rule 703. Like the Alito plurality, she might say that the factfinder can rely on her expert's belief that Cellmark produces correct results because experts in the field reasonably rely on the fact that accredited laboratories always get things right. But even if the factfinder could possess such confidence in an outside laboratory, it does not change the hearsay nature of the statements from Cellmark. The surrogate expert's confidence, or the fact that Cellmark is accredited, just supplies a possible reason to believe the truth of the statements that, ostensibly, were not introduced for their truth. At best, this kind of circumstantial evidence could overcome a motion for a directed verdict if the ISP's analyst's references to what Cellmark reported were introduced for their truth—which the Confrontation Clause prevents—or for some other purpose—which is not present here.

${ }^{100}$ Id at 2238 (Alito) (plurality). 
The factfinder can, Justice Alito suggests, believe in the accuracy of Cellmark's profile because of the eyewitness identification of the person said to match, rather than needing to rely on Lambatos' assertion of her own reliance and her own belief in its trustworthiness. (This is what, for Justice Alito, constitutes the other evidence of Cellmark's reliability that permits Opinion 1, discussed above, to be taken as "premise-only.")

This "striking" coincidence about the table of alleles in the Cellmark report calls to mind Bridges $v$ State, ${ }^{101}$ a well-known case about the limits of the definition of hearsay. In that case, a man was charged with sexually molesting a minor. Among the evidence presented were statements made by the victim to her mother and the police shortly after the incident, describing details of the perpetrator's house, furnishings, and location, including certain unusual details, such as a white, fenced playhouse set back from the street directly across from the house into which she was taken. Later, other, admissible evidence established the accuracy of the girl's description, including the general accuracy of the unusual and specific details she had recalled. Additionally, in the circumstances of this case, there was absolutely no other conceivable explanation for the young girl having ever been in this room or this house on some other occasion, nor any other plausible way she would have known of its description. The court determined that in this unusual situation, the girl's out-of-court statements about where she was molested did not constitute hearsay. Her statements were admissible, the court said, not to prove the existence of the particular items or locations she described, but rather to prove, circumstantially, her knowledge of these things, which tended to prove that she had in fact been in the room, given that the room's description and location were unequivocally established by other, admissible evidence. ${ }^{102}$

Bridges has been controversial among evidence analysts. Some have argued that this evidence ought still to be viewed as hearsay and that this "circumstantial evidence of knowledge or state of mind" has no limits and could eviscerate the hearsay rule. ${ }^{103}$ However, the argument that the statements are not hearsay is that, given these circumstances, including the existence of other evidence to support the accuracy of the girl's description, the young girl's statements do not need to be taken as true; rather, the very fact that she could describe such a room, proven to exist by other evidence, suggests that she was in fact in such a room-not because she says so, but because the chances of her being able to make up a description based on her imagination or other sources of knowledge is massively implausible and thus extraordinarily unlikely to be the result of mere coincidence or chicanery. So for her to be able to describe the room, with telling and specific detail that turned out to correspond in every particular to an actual room, provides strong circumstantial evidence that she was, in fact, in that same room, separately and apart from her saying so. Indeed, if she had said, "Let me tell you about a room I have never seen," and went on to describe it in the same vivid detail, that too would provide circumstantial evidence that she had, in fact seen it, her claim to the contrary notwithstanding.

Justice Alito did not cite Bridges, but his rationale is structurally quite similar. He suggests that the eyewitness identification by the victim of the person whose profile was returned by Cellmark circumstantially establishes the accuracy of Cellmark's analysis, and hence, Cellmark's profile can meaningfully be mentioned by the expert for a purpose other than the truth of its contents. But there is a difficulty. That Cellmark reported the alleles of a man

\footnotetext{
10119 NW2d 529 (Wis 1945).

102 Id at 536.

${ }^{103}$ See, for example, Edmund Morgan, Evidence 1941-1945, 59 Harv L Rev 491, 544 (1945); G. Michael Fenner, Law Professor Reveals Shocking Truth About Hearsay, 62 UMKC L Rev 1 (1993).
} 
subsequently identified by the victim in a line-up does provides some independent evidence of the accuracy of its analysis, but not nearly so much as the plurality proposes. The fact of a database match shows us that the alleles that Cellmark returned to the ISP (1) in fact matched someone in the database (indeed, a man in the same geographical vicinity as L.J., notwithstanding that Cellmark handled samples from across the country); and (2) that when this man was included in a line-up, he was the very person identified by L.J. as the perpetrator. Had its table of alleles been plucked from the air, there most likely would not have been a match to anyone in the database. Had Cellmark fumbled the chain of custody and analyzed the wrong rape kit leading to a hit to the wrong man in the database, L.J. might not have identified this man in the line-up as her assailant. So Justice Alito is correct that this does provide some circumstantial support for the inference that Cellmark sent back the appropriate sample and engaged in an accurate analysis.

But how strong is this evidence? To answer this, we would need to understand both the probability of an incorrect set of alleles matching at least one person in the state database who would not be dismissed out of hand as the possible rapist, and the probability of L.J. making an erroneous eyewitness identification of this individual. With regard to the first issue, it should be clear that trawling large databases creates many opportunities for even an incorrectly generated DNA profile to match somebody. ${ }^{104}$ Whatever that probability is, it is well above zero. Furthermore, one should not ignore the possibility of a sample switch in the course of the laboratory's processing of rape kits. What if Cellmark had somehow swapped this sample sent from the ISP containing L.J.'s vaginal swabs with another sample sent from a different Chicagoarea case? It is far from obvious that a different potential rapist would not also be in the database. It may be fair to assume that both of these probabilities are small, but it is worth noting both that we do not know what they are, and that they do affect the strength of the circumstantial chain of inferences that runs from the fact of a match to the accuracy of the Cellmark report.

As for the second apparently surprising fact, it depends on the chances for an erroneous eyewitness identification. If we thought that L.J. was extremely unlikely to make a mistake in identifying the perpetrator, then her identification of Williams does provide substantial support for the premise that Cellmark returned the correct sample and that it analyzed the DNA correctly. But imagine, instead, that L.J. was not an especially careful observer, or suppose that some aspect of this specific identification procedure was psychologically suggestive and thereby raised the chances that any observer would pick the defendant from among the possibilities. The opinions do not tell us how many individuals were included in the line-up. We know nothing from the opinions about the specific procedures used. We do not know, for example, whether the person conducting the line-up knew which member was the actual suspect, or whether the police took other protections that have been shown to reduce the rate of erroneous identification. Some evidence in the case suggested that L.J. may have initially identified someone else as the perpetrator, shortly after the attack, strengthening an inference that L.J. could have been susceptible to making an erroneous identification. ${ }^{105}$ The substantial length of time-fourteen months - that had passed between the attack and the line-up procedure that included Williams, also decreases the probative value of her identification, since her memory could have faded over that period and the perpetrator's appearance could have changed. What if L.J. was likely to select someone from the identification, whether the actual perpetrator was present or not? In that case,

\footnotetext{
${ }^{104}$ See David H. Kaye, Rounding Up the Usual Suspects: A Legal and Logical Analysis of DNA Database Trawls, 87 N Car L Rev 425 (2009)

${ }^{105}$ People v Williams, 385 Ill App 3d 359, 361 (2008).
} 
if there were five people in the lineup, there would be a 20 percent chance Williams would be selected at random; if ten people in the lineup, a 10 percent chance.

Admittedly, we have no way to quantify the chances of either a laboratory slip-up or an erroneous identification. But we can be confident that those odds, whatever they might be, are far higher than the one-in-many-quadrillion random-match probabilities presented for Williams' DNA. Note that the parallel to Bridges is not precise. In Bridges, the argument was that the other evidence established the description of the room and area; the girl's description was therefore not hearsay, but it was admissible to demonstrate her knowledge. Without her out-ofcourt statements the prosecutor would have been missing a critical piece of the story. By contrast, in Williams, the argument suggested by Justice Alito is that the fact of the DNA match coupled with the eyewitness identification provides strong circumstantial evidence of Cellmark's accuracy, both that they examined the correct sample and that they performed their testing procedures correctly. Therefore, the expert's references are not hearsay because they are, in a sense, cumulative, or unnecessary. They need not be taken as true because other evidence establishes the same thing; hence his argument that they can be what we termed "premise-only."

This leaves us with the question whether the coincidence of an eyewitness identification of Williams coming in the wake of Cellmark's report is so striking that it transforms the analyst's statements from hearsay into surplusage. We have our doubts. If there had been a laboratory error in which samples were swapped, or some other inaccuracy in Cellmark's process, there could nonetheless be a nonnegligible possibility of an erroneous eyewitness identification. Thus, on the facts of Williams, the probative value of the eyewitness identification as evidence of the laboratory report's accuracy is not as strong as the probative value of a young girl being able to provide multiple, detailed, specific descriptions of an unusual place, as evidence that she had been in that place at some point. Moreover, the chain of inference from the expert's testimony about Cellmark (taken as true) to her conclusion is far more straightforward than the circumstantial chain the plurality opinion posits as an alternative (and that was never directly argued at trial). Still, Justice Alito is correct that these other items do provide some quantum of evidence supporting the accuracy of Cellmark's results, separate from the expert's say-so, if not quite so overwhelming a quantum as he suggested. His argument, while perceptive, is not entirely persuasive.

At the same time, there may be cases in which this argument would be compelling. For instance, the circumstantial evidence would have been significantly stronger if the ISP laboratory and Lambatos had not only looked at the defendant profile, but independently compared the victim's profile as reported by Cellmark to an independently-collected sample of L.J.'s profile. If those female samples matched, that could have provided an additional, probative, circumstantial piece of evidence suggesting the accuracy of the male DNA found in the same swab, and greatly decreasing the chances that the eyewitness identification was a mere coincidence. It would have made a sample swap significantly more unlikely, since it would show that the female portion of the samples clearly were not swapped; and the accuracy of the process as applied to L.J.'s DNA would provide circumstantial evidence of the accuracy of the process applied to the male portion as well. Then, we would indeed have a story of remarkable coincidence comparable to Bridges. We would know that a sample was sent to Cellmark, and a sample was returned form Cellmark with the appropriate label, and furthermore, that the female portion of that sample correctly matched the victim in the case, and the male portion of the sample matched someone in the database who the victim subsequently identified as her perpetrator. While even this additional piece of evidence would not absolutely remove all possibility of some kind of laboratory 
inaccuracy, this body of circumstantial evidence would substantially reduce the possibility of a sample swap or some other error within Cellmark. On those facts, it would be easier to make the argument about the strength of the circumstantial proof no longer requiring or inviting the factfinder to take Lambatos' testimony as evidence of the reliability of Cellmark's analysis. Such facts would bring this case more in line with the approach taken in Bridges.

As in the previous Section, we see that the argument that expert evidence can be offered for a purpose other than the truth is, on occasion, plausible. In some circumstances, Justice Alito's "premise-only" way of understanding some expert disclosure might be credible. But to be able to argue that expert disclosure does not also provide corroboration or bolstering of the other evidence, information that the factfinder-perhaps especially in jury trials but possibly in bench trials too-will be tempted to take as true, this other evidence would need to be extremely strong. We are doubtful that the circumstantial evidence of reliability on these facts is so overwhelmingly strong that the expert's assertions about it were taken by the factfinder as mere surplusage. Moreover, even if Justice Alito's argument holds some water here, in many cases, there will not be substantial independent evidence to support the expert's basis. We take that issue up in the next Section.

\section{B. RULE 703 AND RELEVANCE}

The plurality's dogged determination to cast the expert's testimony strictly premise-only leads to a puzzling discussion of the need for independent evidence of the necessary facts preceding the short-chain reasoning that starts with the alleles specified by Cellmark and concludes with the expert's attribution of them to Williams (Opinions 2 and 3) ${ }^{106}$ Suppose that L.J. had failed to make an identification of the defendant in the lineup. In that case, there would have been no independent evidence from which a factfinder could infer the accuracy of the alleles Cellmark reported as coming from the semen on L.J.'s swab. Would this require the information from Cellmark to be acknowledged as being introduced for the truth of its contents, and thus problematic under the Confrontation Clause? Justice Alito flatly denies this possibility, asserting that "even if the record did not contain any evidence that could rationally support a finding that Cellmark produced a scientifically reliable DNA profile based on L.J.'s vaginal swab, that would not establish a Confrontation Clause violation." 107 The absence of "proof that Cellmark produced an accurate profile based on that sample," he contends, would render "Lambatos' testimony regarding the match . . . irrelevant, but the Confrontation Clause ... does not bar the admission of irrelevant evidence, only testimonial statements by declarants who are not subject to cross examination." 108 Confining his vision to premise-only testimony, he states that if there is not "independent admissible evidence to prove the foundational facts that are essential to the relevance of the expert's testimony, then the expert's testimony cannot be given any weight by the trier of fact." 109

This position would make sense if we truly viewed Lambatos's testimony as akin to a hypothetical question. Suppose she had testified, "While I cannot myself speak to the accuracy of Cellmark's report, nor can I confirm that they returned the correct sample, if they did in fact return the correct sample along with a correct analysis of it, then the DNA from the vaginal swab

\footnotetext{
${ }^{106}$ See Part II.A.

${ }^{107}$ Williams, $132 \mathrm{~S}$ Ct at 2238 (Alito) (plurality).

${ }^{108}$ Id.

${ }^{109}$ Id. (footnote omitted).
} 
matches Sandy Williams.” In that case, Justice Alito would have been correct. First, there would have been no Confrontation Clause problem. Second, without independent evidence of the premises necessary to her conclusion, her opinion would have been irrelevant and not entitled to any weight. But Lambatos did not answer a hypothetical question. Rather, she offered a conclusion that the samples sent to Cellmark and the one the ISP took from Williams in fact matched. In other words, she provided opinions about both the provenance and the nature of the samples based on the report that was not introduced into evidence.

Imagine that she gave her testimony in a case with the same facts but no eyewitness identification, either because L.J. was equivocal at the time of the line-up, or because for whatever reason, no line-up was ever conducted. Putting the Confrontation Clause issue to one side, Rule 703 probably would allow this testimony. Rule 703 explicitly permits an expert to rely upon inadmissible evidence to support a conclusion, so there would be nothing wrong with Lambatos relying upon Cellmark's report, presuming that it is indeed reasonable for DNA analysts to rely on profiles produced by other accredited laboratories (and it is difficult to argue that it is not). This kind of reliance-like one doctor relying on an X-ray produced by anotheris precisely what Rule 703 permits. Under Rule 703 and most state equivalents, unlike the method for adducing expert testimony prior to the Federal Rules, the proffering party does not need to produce independent evidence of the foundational facts supporting the expert's conclusion as a precondition for admissibility of the conclusion. ${ }^{110}$ Moreover, a factfinder is permitted to give weight to that expert's conclusion even if the foundational facts are never disclosed. Indeed, Rule 703 disfavors such disclosure precisely because of the risk that if disclosed, the factfinder will take them as true. ${ }^{111}$ So under the conventional understanding of Rule 703, if Lambatos's basis evidence did not create a Confrontation Clause problem, and if her reliance on Cellmark's report to establish both the provenance and nature of the samples was reasonable, her conclusions certainly would not be barred as irrelevant, even were there no other evidence to support the accuracy of Cellmark's DNA analysis. The whole thrust of Rule 703 is to dispense with the common-law requirement that experts must base their conclusions on otherwise admissible evidence-the rule creates no requirement that other evidence corroborate the data or facts upon which an expert relies.

If Justice Alito's intimations implying that admissible evidence supporting the expert's basis is a prerequisite for a factfinder to give any weight to expert opinions were applied to all expert evidence, expert witness practice would be radically altered. Applied literally and sweepingly, these dicta would unmake Rule 703's provision that expert conclusions can be admissible even when an expert's basis evidence is not itself admissible! Surely Justice Alito did

\footnotetext{
${ }^{110}$ To be sure, under Daubert v Merrell Dow Phramceuticals, 509 U.S. 579 (1993), a court may require information about these foundational facts in order to assess the validity of the testifying expert's conclusion, but the information supporting validity considered by the judge need not itself be admissible evidence. See FRE 702; FRE 104(a).

${ }^{111}$ FRE 703. Rule 703 therefore partially enacts a deferential approach to a factfinder's assessment of expertise, in which a factfinder may credit a conclusion of an expert, even without knowing of the basis or the reasoning process that has produced it. On deference versus education in the assessment of expert evidence, see Ronald J. Allen and Joseph S. Miller, The Common Law Theory of Experts: Deference or Education, 87 Nw U L Rev 1131 (1993).
} 
not mean to state that, in all situations, relevance requires independent evidence proving the truth of the underlying facts essential to an expert's conclusions. ${ }^{112}$

In the wake of Williams, it would be both unfortunate and a violation of common sense if lower courts were simply to interpret the case as standing for the idea that expert basis evidence can be legitimately introduced for a purpose other than the truth of its contents, and hence, because the disclosure is for a nonhearsay purpose, the Confrontation Clause is not implicated. ${ }^{113}$ First, at least five Justices disagreed with that view. Second, even those who adhered to the plurality opinion engaged in a set of justifications that were dramatically case-specific - that this was a bench trial rather than a jury trial and that there was some degree of circumstantial evidence to support the basis (albeit less than the plurality suggests). As a consequence, Williams cannot fairly be read as legitimating a mechanical and broadbrush application of a nonhearsay purpose under Rule 703-though we suspect that many courts will interpret it that way. Partly that will be because of the opacity of a case that has no shared conceptual basis of a majority of Justices for its resolution. Partly that will be because most of the lower courts have been resistant to Crawford and its progeny and will therefore likely jump at the chance to take a more permissive approach than the previous cases in the trilogy permitted. And partly that will be because the no-TMA argument, although often resting on a fictional basis, is an appealing way to treat science as special without appearing to engage in science exceptionalism for Confrontation Clause purposes.

Under this argument, experts can remain formally subject to the Confrontation Clause's strictures, just like any other kind of witness. But since laboratory reports will typically satisfy Rule 703, experts would be able to rely on them even though they are, per Melendez-Diaz, testimonial. Note that there is no explicit, overt science exceptionalism in this approach-the claim is that the Confrontation Clause applies to all evidence so long as it is offered for the truth of the matter asserted. Instead, Confrontation Clause jurisprudence simply builds on Rule 703's own ways for treating scientific evidence differently from other kinds of evidence-both in that experts can rely upon (and sometimes disclose) inadmissible evidence, and in that, for a set of context-specific reasons born in the previous Confrontation Clause era, there has been widespread acceptance of the no-TMA claim about basis evidence. Under the Williams approach, there is no need to exempt forensic science reports completely from the Confrontation Clause; instead, the no-TMA argument merely declaws the Clause in the forensic context.

112 Justice Alito wrote that 'Of course, Lambatos' opinion would have lacked probative value if the prosecution had not introduced other evidence to establish the provenance of the profiles, but that has nothing to do with the truth of her testimony.” $132 \mathrm{~S} \mathrm{Ct}$ at 2239. Perhaps this dictum pertains only to opinions whose relevance vel non depends on the fulfillment of some condition of fact. Under Rule 104(b), there must be some evidence of the underlying condition. It is true that Lambatos's opinion about a match between the alleles she considered in querying the database and Williams' alleles could be seen to pose a conditional relevance issue. This opinion would be irrelevant in the absence of proof that the alleles she used had the proper provenance, i.e., that they were in the vaginal swabs from L.J. And, there was some "other evidence" of this in the form of the FedEx documents. But Lambatos also seems to have formed her own opinion about provenance. Even without the shipping documents, if it is reasonable for an ISP analyst to rely on the statements in reports from other laboratories to form opinions about provenance, then under Rule 703 the factfinder may rely on such an opinion to find, under Rule 104(b), the requisite relevance in an opinion about the database match.

113 Alas, some courts are already beginning to do precisely this. See, for example, People v Viera, No. B230802, 2012 WL 2899343, *11 (Cal App Ct 2012); McMullen v State, 730 SE 2d 151, 160 (Ga App Ct 2012). 
To be fair, the plurality's arguments do have less reach than a total exemption of the sort seemingly favored by several Justices. After Williams, it is still not permissible to introduce a report without any expert as all, as was commonplace before Melendez-Diaz. Moreover, it would be strained to permit the testimony of a surrogate witness with no direct involvement in the testing, as in Bullcoming-but as much because of the limitations of the rules of evidence that prohibit one expert from merely serving as a mouthpiece for another, ${ }^{114}$ as because of the Confrontation Clause itself.

\section{CONFRONTING SCIENCE: THE FUTURE}

The trilogy of laboratory cases marks the outer boundaries of what the Confrontation Clause allows for evidence on the findings of laboratory scientists or technicians whom the prosecution does not make available for cross-examination. At one pole are (a) highly formal reports or (b) testimony from an expert with no connection to the specific laboratory analyses to the effect that the contents of those solemn reports are true. The formal reports themselves are inadmissible. That is the teaching of Melendez-Diaz. In addition, the testimony about the truth of the contents is inadmissible if provided by experts unconnected to the specific test. That is the lesson of Bullcoming. At the other pole are written reports (a) not emblazoned with seals or attestations and (b) generated before a specific suspect or desired outcome was known to the laboratory staff. These reports the Williams majority should find acceptable even without a surrogate witness.

These latter outcomes follow from two unpopular theories- the William's plurality's noaccusation theory - and Justice Thomas's no-formality theory. They are unpopular in that a majority of the Williams Court expressly rejected the no-accusation theory, and only a single Justice subscribed to the no-formality theory. Deciding more cases on theories that most of the Court rejects seems perverse. ${ }^{115}$ It may be the way things are for the moment, but without a more appealing doctrine, it may constitute an unstable equilibrium.

In between these extremes is a much larger and murkier zone of hypothetical questions (discussed in Williams), machine-generated results (mentioned in Bullcoming as possibly lying outside the clause), and surrogate witnesses (left largely unresolved by Williams). As for hypothetical or conditional questions, the major Williams opinions allow that the Confrontation Clause is no barrier to asking a witness to draw expert inferences conditional on the truth of other experts' work. For example, a prosecutor seeking to introduce the ISP analyst's opinion in Williams could have posed questions that might have been answered as follows:

Q. Did you review the report that Cellmark sent back?

A. Yes.

Q. Did Cellmark report any alleles as being present in the vaginal swab and as not coming from L.J.'s DNA?

A. Yes.

Q. Could those alleles have come from the semen that your laboratory detected in the vaginal swabs that it shipped to Cellmark?

A. Definitely. Semen contains DNA, and it was present in the swabs.

\footnotetext{
${ }^{114}$ Kaye, et al, Expert Evidence §4.7.1 at 176-77 (cited in note 31).

${ }^{115}$ But see Leo Katz, Why the Law is So Perverse (Chicago 2011).
} 
Q. Did you search the Illinois database of DNA profiles from known individuals to see whether any of them were consistent with those DNA alleles that Cellmark attributed to the semen?

A. Yes.

Q. How many matches were there?

A. Only one.

Q. What is the name of that one and only matching individual?

A. Sandy Williams.

Q. Is there much of a chance of anyone else in the Chicago area besides Mr. Williams having a similarly matching profile?

A. This profile would be expected to occur in approximately 1 in 8.7 quadrillion black, 1 in 390 quadrillion white, or 1 in 109 quadrillion Hispanic unrelated individuals. ${ }^{116}$

This line of questioning is entirely compatible with the Confrontation Clause. The confrontation problem does not arise unless or until the prosecution presents evidence that would allow the factfinder to accept the unstated premise that Cellmark correctly deduced the alleles of the unknown rapist.

But skirting the confrontation problem in this way introduces the vexed evidentiary problem known as "conditional relevance." 117 This witness has said nothing about the truth of Cellmark's report that the alleles are attributable to the semen. Without proof that Cellmark's report is true, the expert opinion that builds on it may be irrelevant. To satisfy this relevance requirement, the prosecution could try to introduce the Cellmark report into evidence-except that Melendez-Diaz bars that move unless the state also produces the Cellmark analysts. Could the prosecution establish the necessary condition through the ISP expert herself? If knowledgeable, she could testify to how wonderful and careful Cellmark's work always is, giving the factfinder a reason to accept the statements in the report, and hence, the ISP expert's finding of a very probative match. ${ }^{118}$ This testimony about Cellmark resolves the conditional relevance problem, but it re-introduces the confrontation problem of proving the facts on which the match and its associated probabilities rest without calling the witnesses to these facts. The sole testifying expert, like the one in Bullcoming, had no involvement in Cellmark's work, and, as we have seen, Rule 703 offers no way out because the statements are not admitted for the noTMA purpose that sometimes, albeit rarely, legitimately applies.

To break out of this loop, the prosecution might try calling a surrogate witness who is directly involved in at least one major step of the laboratory's testing and is familiar with the whole procedure. The Justices' opinions in Williams and Bullcoming display some nonspecific openness to the use of surrogate or synthesizing witnesses in this type of situation. When many workers contribute to the final conclusion and some of them perform rather mechanical

\footnotetext{
${ }^{116}$ The last answer is taken from the trial transcript. See Joint Appendix (cited in note 40). However, it is not quite responsive to the question because it does not account for relatives and because Sandy Williams' profile was not the only one that was consistent with the allele table in Cellmark's report. On the latter point, see Kaye, Williams v. Illinois-Part II (cited in note 83).

${ }^{117}$ See Richard D. Friedman, Refining Conditional Probative Value, 94 Mich L Rev 457 (1995); Dale A. Nance, Conditional Relevance Reinterpreted, 70 BU L Rev 447 (1990); David S. Schwartz, A Foundation Theory of Evidence, 100 Georgetown L J 95 (2011).

118 The defense might object that Cellmark's past good acts are inadmissible to show a tendency to reach correct results. See Edward J. Imwinkelried and David H. Kaye, DNA Typing: Emerging or Neglected Issues, 76 Wash L Rev 413 (2001). This too is a relevance-prejudice issue rather than a constitutional question.
} 
procedures, tying up the entire team in court seems extravagant, at least to laboratory administrators as well as to some of the Justices. ${ }^{119}$ And, of course, witnesses become unavailable for reasons beyond the control of the state. But the Justices have yet to coalesce on a workable and shared doctrine to effectuate this pragmatic compromise.

Notwithstanding the Williams plurality's efforts to rely upon Rule 703, we believe that this rule is more a source of confusion that a panacea for the problem of having to assemble an entire team of witnesses from the laboratory. The rule, as originally drafted, was not directed at the disclosure of underlying data. The rule's purpose is to allow an expert witness to testify to a conclusion that reasonably relies on the work of other experts without disclosing that underlying or related work. This expert's conclusion is the focus and gravamen of the rule. As a corollary, the rule allows disclosure of the other experts' out-of-court statements-but only for the limited and often fictional purpose of helping the factfinder evaluate the quality of the testifying primary expert's conclusion and only when the underlying statements are unusually probative of that reasoning. ${ }^{120}$ In the settling dust of Williams, it seems that Justice Breyer was correct. If the Court is to avoid a regime in which every person who comes into contact with forensic science evidence must be produced for cross-examination, it will need to think hard about the function of confrontation and the nature of forensic science evidence. ${ }^{121}$

That takes us back to the still broader question that we suggested that the Court ought not to avoid: whether there is, in fact, a satisfactory justification for giving special treatment to forensic science evidence under the Confrontation Clause. We have seen how the Court has danced around this question, sometimes_as in Justice Kennedy's dissent in Melendez-Diazarguing explicitly that science needs to be treated differently from other kinds of evidence, and on other occasions - as in Justice Alito's opinion in Williams-building on the ways that the evidence rules already treat expert evidence differently to produce a doctrinal framework with the effect of creating special rules for forensic science.

The rules-of-evidence approach is not only unwieldy, but it fails to come to grips with the question of whether science testimony is meaningfully different from other testimony. Are there

\footnotetext{
${ }^{119}$ See generally Williams, 132 S Ct at 2244, 2248 (Breyer concurring).

${ }^{120}$ A 2000 amendment to the rule specifies that "if the facts or data would otherwise be inadmissible, the proponent of the opinion may disclose them to the jury only if their probative value in helping the jury evaluate the opinion substantially outweighs their prejudicial effect.” FRE 703. The Advisory Committee Note accompanying this amendment elaborates:

When information is reasonably relied upon by an expert and yet is admissible only for the purpose of assisting the jury in evaluating an expert's opinion, a trial court applying this Rule must consider the information's probative value in assisting the jury to weigh the expert's opinion on the one hand, and the risk of prejudice resulting from the jury's potential misuse of the information for substantive purposes on the other.
}

Advisory Committee Note, FRE 703.

${ }^{121}$ Arguably, when a laboratory has no idea of whether its preliminary work (such as extracting DNA from a bloodstain, measuring the quantity extracted, and amplifying the extract with PCR) will incriminate anyone at all, statements about these preliminary steps fall short of the accusatory testimonial statements that demand confrontation. Perhaps this theory (which does not cramp the Confrontation Clause to the extent that the "targeted individual" requirement of Justice Alito plurality's opinion does) could deal with the problem of having to call a large number of individuals to prove the truth of every statement about every link in the chain of custody and every step in processing and testing forensic evidence. Additional proposals can be found in Kaye, et al, Expert Evidence § 4.10 (cited in note 31); id. $\S 4.12$ (Supp. 2013). 
justifiable reasons for creating special rules in this context, and if so, what are they? On the one hand, some Justices, like Justice Scalia, seem determined both to deny that there is a critical difference and to assert that even if science testimony is different, it hardly matters. As he said in Melendez-Diaz, "the analysts who swore the affidavits provided testimony against MelendezDiaz, and they are therefore subject to confrontation; we would reach the same conclusion if all analysts always possessed the scientific acumen of Mme. Curie and the veracity of Mother Theresa." 122 On the other hand, some other Justices, most notably Justice Kennedy, emphasize that forensic analysts are simply not like "ordinary" or "conventional witnesses" for myriad reasons. ${ }^{123}$

Notwithstanding Justice Kennedy's emphatic use of the term, prior to Melendez-Diaz, there was no category known as "conventional witnesses." It is true that expert witnesses are granted both certain kinds of special authorization under the evidence rules (such as the ability to give opinions and to rely on inadmissible evidence), and expected to face some special forms of regulation (such as Daubert and the provisos of Rule 702). It could even be said that "expert witnesses" are meaningfully their own category in some respects, a category sometimes used in relation to or in opposition to "lay witnesses," but a well-defined counter-category of "conventional witnesses" simply did not exist. ${ }^{124}$ Still, he is right that there are differences. Non-experts who appear in a criminal case are typically in court to testify about something atypical, have percipient knowledge of either a criminal act or some past events relating to it, and for them, testifying itself is an exceptional occurrence. By contrast, as Justice Kennedy points out, forensic experts have standard protocols, are engaged in routine and regular activities, write their own reports rather than being the subjects of interrogation, and are taking written observations that are contemporaneous (or nearly so) with their scientific observations. These differences, in his view, should make a difference.

Although both Crawford and Melendez-Diaz emphasize that the Confrontation Clause is not supposed to be about reliability - even the evidence of saints is subject to its stricturesreliability still lurks in these opinions. And understandably so. First, it is hard to understand what the Confrontation Clause is for, if not reliability. It might be fair enough to say that a judicial determination of reliability ought not to deprive the factfinder of confrontation as a method for its own independent assessment of reliability, but it is difficult to understand the Confrontation Clause's purpose wholly disconnected from the idea of reliability. (Indeed, Justice Scalia recognizes as much, although he reads the Confrontation Clause as a procedural mechanism that tends toward greater reliability rather than a substantive check). Moreover, when it comes to experts, the Daubert trilogy and its innumerable progeny in the lower courts have made reliability into the clear touchstone for the evaluation of scientific evidence, the evidentiary keyword that governs its assessment by the court. As Justice Blackmun wrote in Daubert, "under the Rules the trial judge must ensure that any and all scientific testimony or evidence admitted is not only relevant, but reliable." ${ }^{125}$

\footnotetext{
${ }^{122}$ Melendez-Diaz v Massachusetts, 557 US 305, 319 n 6 (2009). However, Justice Scalia also takes pain to suggest that the chance of incompetence, corruption, or mere mistake means that the confrontation of experts is not simply an empty formalism. Id at 319.

${ }^{123}$ Id at 345-46 (Kennedy dissenting).

${ }^{124}$ Indeed a LEXIS search indicates a total of four cases using the term "conventional witness" prior to 2009, the year Melendez-Diaz was decided. Justice Kennedy defines his category as "one who has personal knowledge of some aspect of the defendant's guilt.” Id at 330.

${ }^{125}$ Daubert, 509 US at 589.
} 
Like most of the Justices in the science confrontation trilogy, we are dancing around the question of whether science is different. The difficulty is that expert witnesses, including forensic analysts, are neither entirely ordinary witnesses nor entirely unlike ordinary witnesses. Like ordinary lay witnesses, they can misperceive, make mistakes, misinterpret. They can be subject to cognitive biases. They can lie, mischaracterize, or overstate. As Justice Scalia recognizes,

Nor is it evident that what respondent calls "neutral scientific testing" is as neutral or as reliable as respondent suggests. Forensic evidence is not uniquely immune from the risk of manipulation. According to a recent study conducted under the auspices of the National Academy of Sciences, "[t]he majority of [laboratories producing forensic evidence] are administered by law enforcement agencies, such as police departments, where the laboratory administrator reports to the head of the agency." And "[b]ecause forensic scientists often are driven in their work by a need to answer a particular question related to the issues of a particular case, they sometimes face pressure to sacrifice appropriate methodology for the sake of expediency." A forensic analyst responding to a request from a law enforcement official may feel pressure-or have an incentive - to alter the evidence in a manner favorable to the prosecution. ${ }^{126}$

But it is also true, as the dissent in Bullcoming explains, that forensic science reports are often

prepared by experienced technicians in laboratories that follow professional norms and scientific protocols. In addition to the constitutional right to call witnesses in his own defense, the defendant in this case was already protected by checks on potential prosecutorial abuse such as free retesting for defendants; result-blind issuance of reports; testing by an independent agency; routine processes performed en masse, which reduce opportunities for targeted bias; and labs operating pursuant to scientific and professional norms and oversight." 127

We will not here succeed in resolving to what degree forensic science witnesses are different from ordinary ones. But we do wish to suggest one extremely important feature of most science that has implications for how we think about science under the Confrontation Clause and that, as Justice Breyer recognized in Williams, will need to be confronted explicitly. In thinking about why scientific evidence might warrant some limited special treatment, it seems to us that the most important feature of science is that it is a collective, rather than an individual enterprise. ${ }^{128}$ Most scientific experiments, research project, analyses and tests are not carried out by a single individuals acting in isolation. ${ }^{129}$ Certainly one can find instances of an individual

${ }^{126}$ Melendez-Diaz, 557 US at 318, citing National Research Council of the National Academies, Strengthening Forensic Science in the United States: A Path Forward 183 (National Academies 2009).

${ }^{127}$ Bullcoming, $131 \mathrm{~S}$ Ct at 2726-2727 (Kennedy dissenting).

128 The point is well established in the sociology of science. See Carlo Mongardini and Simonetta Tabboni, eds, Robert K Merton \& Contemporary Sociology (Transaction 1998).

${ }^{129}$ Any broad-brush claim of this kind is an oversimplification, since "science" is a capacious category and includes substantial variation upon any given dimension, including this one. For an interesting book capturing the epistemic diversity of science - but also illustrating that knowledge is a collective enterprise, albeit to different degrees and in different ways, see, for example, Karien Knorr-Cetina, Epistemic Cultures: How the Sciences Make Knowledge (Harvard 1999). The book contrasts the epistemic culture of high energy physics with that of molecular biology. Although she argues that high energy physics is a collective culture and molecular biology an individual one, her examples actually illustrate that there are collective dimensions in both domains. See Ronald N Giere, Distributed Cognition in Epistemic Cultures, 69 Phil Sci 637 (2002) (reviewing Knorr-Cetina). 
experiment conducted by a scientist working alone (though even this solo scientist must rely on the contributions of others-purchasing reagents or laboratory equipment that embodies the expertise of others, or building on experimental results conducted by others). But most scientists simply do not operate solo. This is true across virtually all domains of science-from the high energy physics experiment that involves hundreds or even thousands of collaborators, to the social psychology experiment conducted by a far smaller team. And it is also true of forensic science test procedures.

This reality is not lost on the Justices struggling with forensic science and the Confrontation Clause. In Williams, Justice Breyer wrote, "Experts-especially laboratory experts-regularly rely on the technical statements and results of other experts to form their own opinions. The reality of the matter is that the introduction of a laboratory report involves layer upon layer of technical statements (express or implied) made by one expert and relied upon by another."130 As practiced in most laboratories, DNA analysis, for example, is a collaborative endeavor, involving multiple analysts, each of whom conducts one (or more steps) that subsequent analysis relies upon. Indeed Justice Breyer's concurring opinion included an appendix describing, flow-chart style, the many different steps that may be taken by as many as a dozen different analysts, conducting a singular regular DNA profile comparison. ${ }^{131}$ Must all of them testify in every case? Can it really be that the Confrontation Clause requires "turtles all the way down" 132 ? Are we doomed to face a regress of experts, where each has relied upon the one before, who now must also testify?

By contrast, a “conventional witness,” to borrow Justice Kennedy’s nomenclature, does not usually testify about knowledge produced through such a collective, interconnected process. Usually, such a witness testifies to firsthand, personal observations. While these may include the statements of others - which would be hearsay if introduced for their truth - this witness' testimony, beliefs, and observations typically do not intrinsically depend on a complex web of trusted activities conducted by others, or at least not to the same degree. Typically, a "conventional witness" may have seen or observed something that has probative value only in connection with other evidence. To borrow the evidentiary truism, a brick is not a wall; a given witness's testimony may be merely a modest brick that has to be integrated with other evidence to be persuasive on any matter of import to the case. But it is the factfinder who is asked to make these links, not the witness. When the conventional witness testifies to "bricks" within his first-hand knowledge, his knowledge does not depend on the other bricks in the same way that an expert's often does. To be sure, outside of the courtroom, he might think of himself as having knowledge of some of these other "bricks" as well, based on hunch, speculation, inference, or the testimony of others. But in court, his testimony is limited, as much as is practicable, to the

Note also, that we are going to bracket entirely the question of how to define science, and simply operate here with an imprecise, but generally shared understanding. In doing so, we recognize that some critics - including us - have argued that forensic science is not always as scientific as it purports to be and operates within an inadequate research culture. Jennifer Mnookin, et al, The Need for a Research Culture in the Forensic Sciences, 58 UCLA L Rev 725 (2011). Although there are significant limitations and problems with some forms of forensic science, we do not think that these weaknesses remove the enterprise from the realm of science, broadly defined.

${ }^{130}$ Williams, $132 \mathrm{~S}$ Ct at 2246 (Breyer concurring).

${ }^{131}$ Id at 2252-2254.

${ }^{132}$ Stephen Hawking, A Brief History of Time 1 (Bantam 1988). 
matters that do not depend on factual knowledge that stems from sources outside his own observation. ${ }^{133}$

By contrast, the knowledge claims of forensic science witnesses are, intrinsically, strongly interlinked with the actions and knowledge-production of others. Expert opinions and conclusions, inevitably and necessarily, require reliance on materials produced by others, data provided by others, and judgments and opinions reached by others. It is not an exaggeration to say that the knowledge that is produced through the exercise of expertise is inherently collective knowledge. It requires reliance on what others have done and what others know. This, of course, is precisely why Rule 703 permits experts, unlike lay witnesses, to rely on data and materials provided by others in forming their own conclusions. Doing so is part of what it means to engage in complex inference and knowledge production. Experts, in the course of their daily work, are engaged in a form of "collective" or "distributed cognition," in which they produce knowledge together that would not be available to any one of them standing alone. The knowledge is distributed across a group of experts, rather than being held by any single individual. ${ }^{134}$ These individuals produce knowledge collaboratively, that is not truly held by any one of them alone. In a sense, the knowledge belongs to the network rather the individual. Collaborators create formal or informal procedures and mechanisms that both generate and rely upon trust, but there is inevitably an "epistemic dependence" 135 upon one another.

Returning to the Confrontation Clause conundrums, much of the time, the materials, data, and opinions upon which an expert relies, or the other individuals and elements within the expert's network of distributed cognition, will not itself be testimonial. The operator of a breathalyzer relies upon a machine he himself likely only partly understands-enormous technical knowledge is literally built into it. But that knowledge is not testimonial under any of the Court's definitions. The same goes for a forensic pathologist who relies on the deceased's medical records when ascertaining the cause of death. Those medical records are part of the forensic pathologist's basis, but they are not themselves testimonial. So for many kinds of scientific evidence, distributed cognition does directly raise Confrontation Clause problems.

Because of the relatively limited definition of the testimonial, it would be theoretically possible to require each and every testimonial declarant within a forensic science analysis to testify. There is no inherent obstacle besides time and money. All of the roughly dozen analysts who participated in a given DNA extraction and comparison process could come to court to

\footnotetext{
${ }^{133}$ Of course, to paraphrase Quine, all knowledge depends on knowledge outside of specific observation in this case. For example, a witness can only put his observation into language because he already knows about language. He can testify that he smelled tobacco because he already has knowledge of what tobacco smells like. He can testify that the defendant had several drinks because he knows that Jim Beam contains alcohol, etc. Nonetheless, for "ordinary" witnesses, keeping observations as close as possible to the Lockean ideal of direct observation is the aspiration.

${ }^{134}$ See Ronald N. Giere, Scientific Cognition as Distributed Cognition, in Peter Caruthers et al, eds, The Cognitive Basis of Science 285 (Cambridge 2002); P.D. Magnus, Distributed Cognition and the Task of Science, 37 Social Stud Sci 297 (2007), and for a classic in the area, Edwin Hutchins, Cognition in the Wild (Bradford 1995). For an article looking at the way humans can offload knowledge and know-how to technology as well as to other experts, see Itiel E. Dror and Jennifer L. Mnookin, The Use of Technology in Human Expert Domains: Challenges and Risks Arising from the Use of Automated Fingerprint Identification Systems in Forensic Sciences, 9 Law, Probability \& Risk 47 (2010).

${ }^{135}$ For an analysis of epistemic dependence focusing on the structure of expert knowledge, see John Hardwig, Epistemic Deference, 82 J Phil 335 (1985).
} 
describe what they did in turn. This might be highly impractical, but it is possible. ${ }^{136}$ Nonetheless, virtually no one who has thought about the intersection of forensic science and the Confrontation Clause thinks this makes sense. Even Justice Scalia, who is perhaps prepared to go furthest down that path, does not wish to go quite so far. He wrote in Melendez-Diaz,

Contrary to the dissent's suggestion, we do not hold, and it is not the case, that anyone whose testimony may be relevant in establishing the chain of custody, authenticity of the sample, or accuracy of the testing device, must appear in person as part of the prosecution's case. While the dissent is correct that "[i]t is the obligation of the prosecution to establish the chain of custody," this does not mean that everyone who laid hands on the evidence must be called. As stated in the dissent's own quotation, "gaps in the chain [of custody] normally go to the weight of the evidence rather than its admissibility." It is up to the prosecution to decide what steps in the chain of custody are so crucial as to require evidence; but what testimony is introduced must (if the defendant objects) be introduced live. ${ }^{137}$

Justice Scalia tries to escape from the "turtles all the way down" problem by distinguishing chain of custody evidence from substantive analysis, but as the dissent points out, this distinction does not actually provide much assistance. Take the testimony about the chemical makeup of a drug, in Melendez-Diaz. Justice Scalia implies that the person who establishes the accuracy of the testing device is not required, But why not? Is that not a prerequisite to being able to be confident about the accuracy of the result? ${ }^{138}$ Arguably the person who interpreted the result is making the most central bottom line judgment relevant to the defendant. Is this individual therefore the only one who needs testify? What if the technician who prepared the sample somehow contaminated it? Should that technician be required to testify as well? None of these technicians is merely engaged in documenting a chain of custody. They are all taking steps that contribute to the final conclusion about the chemical composition of the substance at issue. They are, in other words, engaged in distributive cognition.

Thus, following to its logical conclusion the claim that testimonial evidence must be presented live would lead to the technically possible, but worrisomely expensive and inefficient position, that every testimonial link in the distributed cognitive chain of experts must be forged with a corresponding witness in court.

At the same time, however, understanding that distributed cognition and epistemic deference are part and parcel of what it means to be doing science may help justify a partial retreat from this unattractive result. This recognition could inform a coherent and constructive analysis of whether, when, and to what degree, a form of science exceptionalism in the Confrontation Clause might be warranted. Recognizing that science is a collective mechanism for knowledge production, a process of distributed rather than individual cognition, and a set of methods that rely upon both skepticism and epistemic dependence should matter, at least to a limited degree. In making this claim, we appreciate that the legal system has its own methods for adducing knowledge. The procedures of science are not, ipso facto, adequate for legal

\footnotetext{
${ }^{136}$ For years, the FBI's DNA laboratory sent all the technicians involved in a particular analysis to testify at the later trial in capital cases if prosecutors insisted that the court would not admit the DNA evidence otherwise. Frequently, the technicians would recite the contents of their reports as to which they had no independent recollection. Interview with Jenifer Smith, Jan. 9, 2012.

${ }^{137}$ Melendez-Diaz, 557 US at 311 n 1.

138 There is a potentially persuasive argument that the calibrator's testimony is so far from being accusatorial that it should not be considered testimonial. See note 121. But that is a different theory than the one we are discussing here.
} 
purposes. The law is free to develop its own rules and requirements-even to the extent of requiring each and every forensic analyst to appear in court. Assertions of dire consequences and an end to forensic testing such as those made by New York City's Chief Medical Examiner ${ }^{139}$ might not sway judges, who might instead expect laboratories to consolidate tasks to require fewer analysts in each case. Surely, if pressed, laboratories could reduce the number of analysts involved in some tests. For example, a DNA analysis and comparison could revert to a process involving, say, three technicians and analysts, not twelve or more. But if we see distributed cognition as a defining feature of science, we recognize that this dilemma cannotand indeed probably should not-be eliminated by expecting laboratories to restructure in fundamental ways to reduce or eliminated the collective nature of the knowledge produced. ${ }^{140}$

Given that the courtroom is a central operating theater for forensic science, draconian Confrontation Clause rules might well motivate laboratories to make such modifications. But if these modifications took laboratories in directions inconsistent with the practices of science more generally, it is far from clear that these would be positive developments. The general problem of forensic science has been inadequate incorporation of the norms and practices that govern scientific knowledge production in other settings. Creating incentives to reduce the degree of distributed cognition would push in the opposite direction. Thus, in the name of confrontation values, which, even if not about reliability per se, are intended as protections enhancing the reliability of evidence, forensic laboratories might instead develop practices that decreased accuracy, transparency, and the creation of a research culture. ${ }^{141}$ Recognizing the valuable dimensions of the collective aspects of science, suggests that this difficulty of the potential expert witness regress cannot and should not be eliminated by expecting laboratories to change their practices. Asking for scientific knowledge to look like that of "conventional witnesses" in this respect is not a viable long-term solution.

Recognizing that there is a certain structural mismatch between the atomized conception of knowledge-provision that undergirds our approach to "conventional witnesses," and the operation of science, may invite openness to some modifications to the Confrontation Clause with respect to expert witnesses. ${ }^{142}$ At the same time, the fact that scientific knowledge is, in some ways, different from lay knowledge, does not justify abandoning the values underlying the Confrontation Clause altogether, nor treating science as if it is self-authorizing or infallible, for surely it is neither one. The question is whether the epistemic values of the Confrontation Clause can be melded with the epistemic realities at work in modern science.

\footnotetext{
${ }^{139}$ Brief of Amici Curiae New York County District Attorney’s Office and the New York City Office of the Chief Medical Examiner in Support of Respondent, Williams v Illinois, No 10-805, *6 (US filed Oct 26, 2011) (available on Westlaw at 2011 WL 5125054) ("Requiring all of those technicians to appear in court for cross-examination would bring forensic work in the laboratory to a halt.”).

${ }^{140}$ Forensic science is also, perhaps, transitioning from a craftsman approach to something closer to an assembly line process. There may be both pluses and minuses to such a transition, discussion of which is beyond the scope of this Article-but if a transition is underway, it also has the effect of increasing distributed cognition.

${ }^{141}$ See generally Mnookin et al., 58 UCLA L Rev at 725 (cited in note 129).

${ }^{142}$ While we have avoided discussing the originalist arguments contained in any of these cases, it is worth noting that this recognition of modern science as a process of distributed cognition might also provide a grounds for justifying treating expert statements differently from other testimonial statements. Arguably, testimony relying on distributed cognition is a modern phenomenon without clear Founding-era equivalents.
} 
We believe there is potential for such compromises. We conclude by briefly offering possible suggestions for such compromises - but we are less wedded to the particulars than to the larger points that (1) the right approach to the Confrontation Clause and forensic science is to ask whether, how, and to what extent science exceptionalism is warranted; and (2) to suggest that the key difference that Confrontation Clause jurisprudence needs to recognize and account for is that science is a collective phenomenon that both produces distributed knowledge and permits, and indeed requires, a certain bounded degree of epistemic deference to the findings of others.

What, then, might these compromises look like? We have mentioned that scientific practices involve a certain degree of trust, epistemic dependence, and deference. But they also often operate through procedures and modes of communication designed to enhance this trust and warrant this deference. Describing the origins of modern science in Leviathan and the Air Pump, Steven Shapin and Steven Shaffer described how Robert Boyle's scientific papers about experiments were self-consciously written to make the scientist readers of them into 'virtual witnesses." 143 His hope was that by reading these immensely and self-consciously detailed accounts, complete with relevant visual depictions, other scientists could almost believe they were present at the experiment itself. Documentation that is both detailed and standardized is a "literary technology" that aids both epistemic deference and distributed cognition. Boyle did not simply ask his fellow scientists to believe him, or to defer to his authority-by documenting in vivid detail what he had done, he transmitted his knowledge partially to those readers sufficiently expert to understand, and thereby enhanced his authority and claims to being believed. ${ }^{144}$

A focus on the adequacy of documentation might be one place to bridge the Confrontation Clause and the practices of experts. For example, we have argued elsewhere that surrogate witnesses should not generally be permitted in lieu of the actual analysis, à la Bullcoming, but that in certain narrow circumstances, they should be deemed permissible. ${ }^{145}$ When the original analyst is unavailable through no fault of the state; when retesting of the evidence specimen is not possible, and when the documentation is sufficiently detailed to permit the surrogate to exercise independent judgment, we have suggested that surrogate witnesses should be allowed. This narrow compromise, we believe, respects both the Confrontation Clause and the processes of science. It is a second-best solution grounded on necessity (hence the requirement for unavailability, parallel to the second-best solution offered in Crawford itself of using a witness' prior testimony upon a showing of both unavailability and a prior opportunity to cross-examine). Given the confrontation value placed on having witnesses who were first-hand participants to the forensic process, if retesting is possible, that should be done rather than using a surrogate with no involvement. But if retesting is not possible, then the adequacy of documentation of the original test-a long-standing scientific strategy for enhancing communication across members of a distributed knowledge network-should permit the use of a surrogate witness who bases his conclusions on the original report coupled with the independent exercise of some degree of his own expertise. To be sure, the surrogate is still relying on the testimonial report. But he is also engaging in distributed knowledge-production, in ways commonplace within the scientific enterprise.

Assuming that they are all available, which members of a distributed knowledge network must testify to satisfy the Confrontation Clause? This framework suggests no simple answer to

\footnotetext{
${ }^{143}$ Steven Shapin and Steven Shaffer, Leviathan and the Air-Pump: Hobbes, Boyle, and the Experimental Life 55-67 (Princeton 1985).

${ }^{144}$ See generally id.

${ }^{145}$ See Kaye, et al, Expert Evidence § 4.10 (cited in note 31); Mnookin (cited in note 13).
} 
this question, but it is nonetheless of some assistance. For no one at all to testify live-as in Melendez-Diaz-violates the Confrontation Clause's strong preference for live testimony. To have everyone involved testify is not only expensive, but it fails to take seriously the collective epistemic aspect of scientific evidence. It treats experts as if they were atomized knowledgeproducers instead of participants in a collective process that permits them a degree of deference, dependence, trust and reliance upon each other's findings. How exactly to "split the baby" is not obvious - should the focus be on the expert who exercised the greatest degree of independent judgment? Should the focus be on the expert at the top of the inferential chain who made the final interpretations and hence was in a position to describe, if not to warrant, the contributions that preceded his own? Should the inquiry be into which witnesses are "central" and which "peripheral," if such categories can be delineated?

We recognize that any determination along these lines will be somewhat arbitrary. We cannot truly argue that recognizing the collective nature of scientific knowledge yields a particular or simple answer. But it does suggest that permitting scientists to engage in some degree of epistemic deference toward the results of their collaborators is, in essence, to permit them to behave like scientists. Again, robust documentation norms may provide a partial palliative. More generally, this framework suggests that even though there may not be one right answer to the line-drawing question, drawing the line some reasonable way is indeed justified, especially when coupled with robust documentation requirements that can improve the degree of justification for epistemic deference by other experts participating in the test process.

Finally, we come back to the facts of Williams. As we have indicated in great detail, we do not think that Justice Alito's no-TMA argument succeeds on the facts of the case, although we do think that on occasion, this argument could work. Could the outcome in Williams have been justified on alternative grounds? The ISP's expert witness was engaged in a mixture of independent judgment and expertise and epistemic deference. She believed the Cellmark report not because she had participated in the analysis, but because it was the report of an accredited laboratory that she believed appropriate to trust unless provided with some reason not to, and no such reason was present in the case. We might reasonably say that the technicians at the ISP and the technicians at Cellmark were engaged in collective knowledge-production, an example of distributed cognition.

We grant that this is a plausible argument. Frankly, we would have preferred to see the Court take up Justice Breyer's challenge and face directly this version of the "who must testify" question. Our view is that the better line drawing would have been to require someone from Cellmark to testify in addition to the witnesses from ISP. While it is certainly possible to draw a large circle of "collective cognition," around both laboratories at once, the two laboratories, hundreds of miles apart, have different protocols, different standard practices, and different internal cultures. The testifying witness knew nothing about these specific protocols. As Justice Kagan points out, the ISP analyst "had no knowledge at all of Cellmark's operations. Indeed, for all the record discloses, she may never have set foot in Cellmark's laboratory." 146 While the testifying expert's reliance may have been warranted from a scientific perspective, the high value placed by the Confrontation Clause's on live testimony for any testimonial statements militates, we think, in favor of requiring someone from Cellmark to testify as well. We do recognize, however, that this conclusion is a judgment call, and that efforts to balance confrontation values with a sensitivity to what is distinctive about science might permit someone else to accept our

${ }^{146}$ Williams, 132 S Ct at 2268 (Kagan dissenting). 
general framework but reach a different conclusion about what was required under Williams' facts.

We end, therefore, by returning to where we began. We have tried to show how the issue of science exceptionalism pervades the new expert evidence trilogy. We do not believe that the Court will achieve a satisfying, persuasive, and workable approach until it forthrightly confronts the question of whether science is special in ways that warrant distinctive treatment under the Confrontation Clause. We have tried to show that this issue of science exceptionalism has been lurking within the various opinions in the trilogy—most explicitly in Justice Kennedy's dissent in Melendez-Diaz, but present to some degree throughout the trilogy.

We believe that the effort to resolve Williams through Rule 703 and the no-TMA argument was a wrong turn. Most of the time, as the dissent in Williams recognized, the no-TMA argument requires implausible mental gymnastics and operates as a legal fiction. There are some limited situations in which expert basis evidence might legitimately be said to be introduced for a purpose other than its truth, but Williams does not present one. In Williams, there is some circumstantial evidence to provide independent support for the Cellmark reports' reliability, but this argument is less persuasive than Justice Alito believed. More fundamentally, it hardly provides a general Rule 703 exception in the Confrontation Clause setting, because most of the time, no such independent basis will be present.

At the same time, we believe that the issue lurking behind, and in good part motivating Rule 703 - the fact that experts almost inevitably do rely on information provided by others-is precisely what might justify a certain degree of special treatment of scientific evidence under the Confrontation Clause. When thinking about how to approach the Confrontation Clause, the distinctive feature of science that requires focused attention is that it is a collective enterprise: it produces distributed knowledge located across individuals rather than held by someone standing alone, and that its participants engage in epistemic deference, deference that is supported by careful documentation. Only by confronting what these aspects of science ought to mean for the operation of the Confrontation Clause will the Court be able to develop an approach to this thorny set of issues that adequately respects both Confrontation Clause values and the practices of science. 